\title{
Effects of temperature and relative humidity on the COVID-19 pandemic in different climates: a study across some regions in Algeria (North Africa)
}

\author{
Abdelmadjid Boufekane $^{1}$ (1) $\cdot$ Gianluigi Busico $^{2} \cdot$ Djamel Maizi $^{1}$
}

Received: 21 June 2021 / Accepted: 1 October 2021 / Published online: 22 October 2021

(C) The Author(s), under exclusive licence to Springer-Verlag GmbH Germany, part of Springer Nature 2021

\begin{abstract}
After more than a year from the first confirmed cases of coronavirus (COVID-19) disease, the role of meteorological factors in the transmission of the virus still needs to be correctly determined. In this scenario of deep uncertainty, the present study aims to investigate the effects of temperature and relative humidity on daily new cases of COVID-19. For this purpose, the COVID-19's development of infection in fourteen Algerian cities characterized by different climatic conditions, during the period from April 1,2020, to August 31, 2020, has been investigated. A detailed time series analysis along with linear regression was used to state a possible correlation among some climate's factor variability (temperature and relative humidity) and daily new confirmed cases of COVID-19. The results showed a weak correlation between daily new cases of COVID-19 and meteorological factors throughout the selected regions. In addition, we concluded that the COVID-19 could fit to high or low values of temperature and relative humidity, and other factors not climates could affect the spreading of the virus like demography and human contact. So, after the discovery of the vaccine and before vaccination of $70 \%$ of the world's population, living with the virus has become an inevitable reality, and it is mandatory to apply the sanitary procedures to slow down the COVID-19 transmission.
\end{abstract}

Keywords COVID-19 $\cdot$ Temperature $\cdot$ Relative humidity $\cdot$ Climatic conditions

\section{Introduction}

During December of 2019, several and anomalous cases of a novel coronavirus disease (COVID-19), classified and now known as severe acute respiratory syndrome coronavirus 2 (SARS-CoV-2) (Gorbalenya 2020; Wu et al. 2020), were registered in Wuhan (China). Starting from March, the number of cases drastically increased also outside China, and the virus still today continues to spread across the whole planet. Specifically, on March 10, 2020, several regions were strongly affected from this new and worried disease: China registered 80,778 total confirmed cases and 3,158 deaths, followed by Italy with 10,156 total cases and 631 deaths, Iran with 8,042 total reported cases and 291 deaths, and finally South Korea where the total cases of COVID-19 were 7,513 with 60 deaths. Forced by this dramatic situation, on March 11, 2020, in sight of the over one hundred thousand $(118,319)$ confirmed cases and with more than 4,000 deaths around the world (World Health Organization (WHO) 2020) the WHO declared the novel coronavirus (COVID19) outbreak a global pandemic. On November 03, 2020, 
Fig. 1 Location of the Algerian studied cities, in different climates

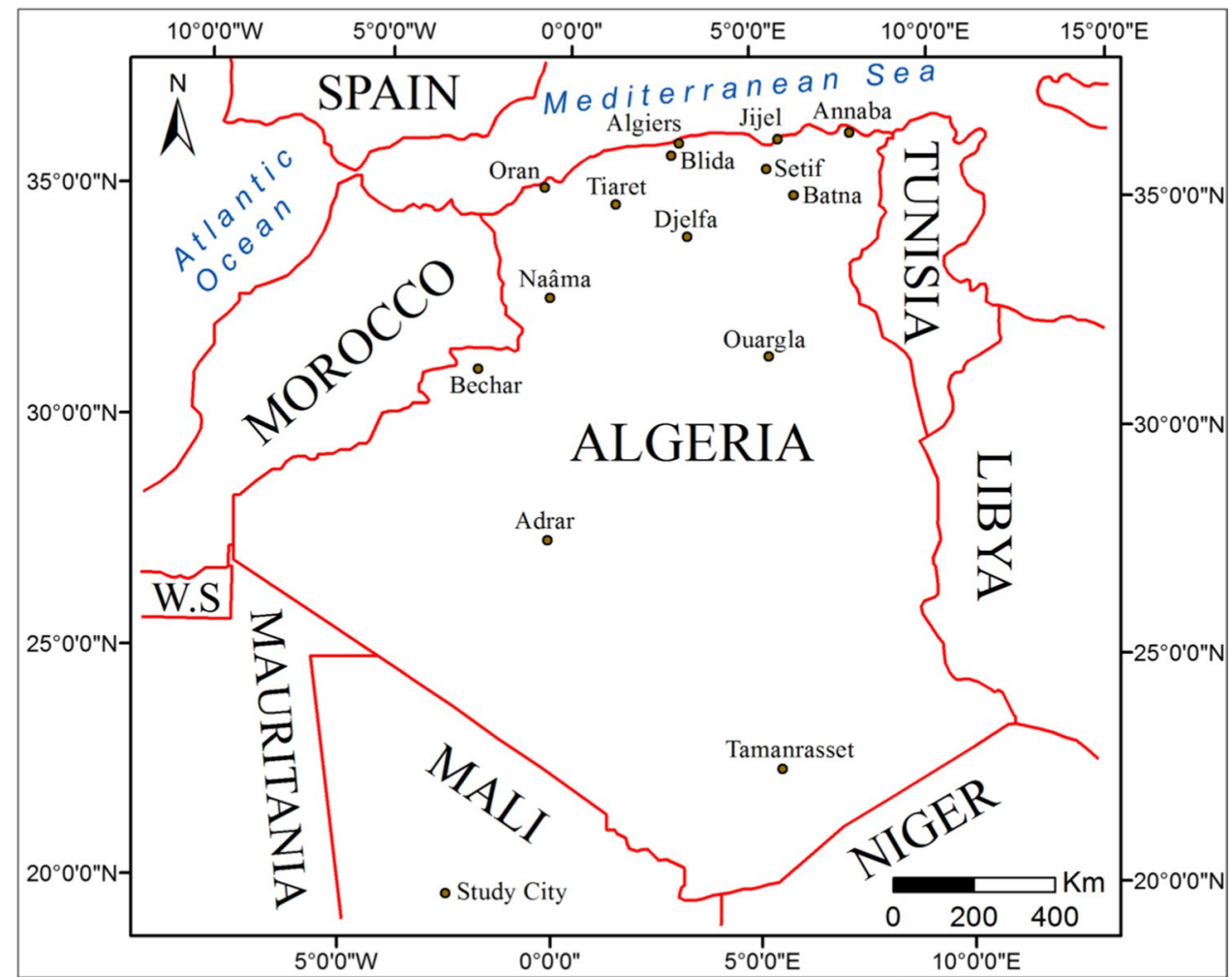

the total infected, in the world, almost reached forty million $(47,277,834)$ with a death toll of over one million peoples $(1,210,328)$. Furthermore, in the middle of April 2021, the total infected exceeds 140 million cases with more than 3,000,000 deaths around the world.

Table 1 Geographic location of cities studied

\begin{tabular}{llll}
\hline Bioclimatic zone & City name & Latitude $\left(^{\circ}\right)$ & Longitude $\left(^{\circ}\right)$ \\
\hline Humid to sub-humid & Algiers & $36.75 \mathrm{~N}$ & $3.03 \mathrm{E}$ \\
& Annaba & $36.90 \mathrm{~N}$ & $7.75 \mathrm{E}$ \\
& Jijel & $36.81 \mathrm{~N}$ & $5.76 \mathrm{E}$ \\
& Oran & $35.71 \mathrm{~N}$ & $0.64 \mathrm{~W}$ \\
& Blida & $36.47 \mathrm{~N}$ & $2.82 \mathrm{E}$ \\
& Setif & $36.15 \mathrm{~N}$ & $5.43 \mathrm{E}$ \\
Semi-arid & Batna & $35.55 \mathrm{~N}$ & $6.16 \mathrm{E}$ \\
& Djelfa & $34.67 \mathrm{~N}$ & $3.25 \mathrm{E}$ \\
& Tiaret & $35.38 \mathrm{~N}$ & $1.31 \mathrm{E}$ \\
& Naâma & $33.26 \mathrm{~N}$ & $0.39 \mathrm{~W}$ \\
Arid & Ouargla & $31.97 \mathrm{~N}$ & $5.38 \mathrm{E}$ \\
& Bechar & $31.61 \mathrm{~N}$ & $2.21 \mathrm{~W}$ \\
Hyper-arid & Tamanrasset & $22.78 \mathrm{~N}$ & $5.52 \mathrm{E}$ \\
& Adrar & $27.86 \mathrm{~N}$ & $0.28 \mathrm{~W}$ \\
\hline
\end{tabular}

In Algeria, North Africa, the first case of COVID-19 was observed on February 25, 2020, while the number of infected today (middle of April 2021) reached almost 120,000 peoples with a number of death equal to 3,148. Currently, the number of new cases rapidly increased in all the five continents, and unfortunately, there are still no effective therapies (drugs) approved by research committee to successfully treat and fight COVID-19 disease. To make matters worse, several researchers have confirmed its transmissibility among peoples (human-tohuman) (Wang et al. 2020a, b) raising the threshold of attention all over the world. Compared to other types of coronaviruses such as the 2002/2003 SARS-CoV and the 2012/2014 MERSCoV (Middle East respiratory syndrome-related coronavirus), the COVID-19 has proven to spread faster. For example, while the MERS-CoV and SARS-CoV took almost 2.5 years, respectively, to infect 1,000 people, the novel SARS-CoV-2 has exceeded this number in only 1 day. Recently, numerous authors have described how the COVID-19 spread can depend on a large number of factors, among which the climatic conditions (Qi et al. 2020; Tosepu et al. 2020). Further, the results of Tian et al. (2021) suggest that COVID-19 patients living in regions with high adverse environmental and climatic factors may be more vulnerable to complications from the virus, specifically higher risk for death. 
Table 2 Weather stations of the study area

\begin{tabular}{llllll}
\hline Bioclimatic zone & City name & Weather station name & Latitude $\left({ }^{\circ}\right)$ & Longitude $\left({ }^{\circ}\right)$ & Altitude $(\mathrm{m})$ \\
\hline Humid to sub-humid & Algiers & Dar El Baida airport & $36.72^{\circ} \mathrm{N}$ & $3.25^{\circ} \mathrm{E}$ & 25 \\
& Annaba & El Mellah airport & $36.83^{\circ} \mathrm{N}$ & $7.82^{\circ} \mathrm{E}$ & 4 \\
& Jijel & Achouat airport & $36.88^{\circ} \mathrm{N}$ & $5.82^{\circ} \mathrm{E}$ & 2 \\
& Oran & Es Senia airport & $35.63^{\circ} \mathrm{N}$ & $0.60 \mathrm{~W}$ & 90 \\
& Blida & Dar El Baida airport & $36.72^{\circ} \mathrm{N}$ & $3.25^{\circ} \mathrm{E}$ & 25 \\
Semi-arid & Setif & Ain-Arnat airport & $36.18^{\circ} \mathrm{N}$ & $5.31^{\circ} \mathrm{E}$ & 1040 \\
& Batna & Batna airport & $35.55^{\circ} \mathrm{N}$ & $6.18^{\circ} \mathrm{E}$ & 1052 \\
& Djelfa & Djelfa & $34.68^{\circ} \mathrm{N}$ & $3.25^{\circ} \mathrm{E}$ & 1144 \\
& Tiaret & Tiaret airport & $35.25^{\circ} \mathrm{N}$ & $1.43^{\circ} \mathrm{E}$ & 978 \\
& Naâma & Naâma & $33.72^{\circ} \mathrm{N}$ & $0.30^{\circ} \mathrm{W}$ & 1166 \\
& Ouargla & Ouargla airport & $31.92^{\circ} \mathrm{N}$ & $5.40^{\circ} \mathrm{E}$ & 141 \\
& Bechar & Bechar airport & $31.62^{\circ} \mathrm{N}$ & $2.23^{\circ} \mathrm{W}$ & 773 \\
& Tamanrasset hyper-arid & Tamanrasset & $22.78^{\circ} \mathrm{N}$ & $5.52^{\circ} \mathrm{E}$ & 1364 \\
& Adrar & Adrar airport & $27.88^{\circ} \mathrm{N}$ & $0.28^{\circ} \mathrm{W}$ & 283 \\
\hline
\end{tabular}

Today, several studies stated a clear relationship between climate characteristics and different types of coronaviruses (MERS-CoV, SARS-CoV-1, SARS-CoV-2). In fact, the latter seems to spread faster under certain weather conditions in terms of temperature and humidity (Marr et al. 2019; Peci et al. 2019; Moriyama and Ichinohe 2019; Shahzad et al. 2021). Generally, all these studies reported a decrease of new observed case accordingly with the temperature increasing, while in opposite, the temperature decrease may increase the virus transmission's risk (Oliveiros et al. 2020; Moriyama et al. 2020; Yao et al. 2020). Furthermore, also a significant correlation with coronaviruses and relative humidity was observed regarding transmission rate (Metz and Finn 2015; Doğan et al. 2020). Zhu and Xie (2020) stated how the absolute humidity is negatively correlated to the COVID19 spread especially in those regions with a wide humidity range. However, correlation of the spread of COVID-19 with climate is not yet clearly stated since none of the mentioned studies states with strong scientific evidence that temperature and humidity could have significant effect on the virus spread. The main limitation of this study was to not proper consider the effects of climate's factor (temperature and relative humidity) in different regions characterized by different climatic conditions to make a proper assertion. Considering such scenario, the aim of this study is to deeply investigate the correlation among COVID-19 spread and local meteorological factors within fourteen cities of Algeria (studies region), with different climates (humid, sub-humid, semi-arid, arid, and hyper-arid) and geographic position to provide useful clarifications for policymakers and the public audience on this possible correlation. A brief literature summary review on recent findings of previous studies has been done to be able to juxtapose our findings in the context of other studies and present a conclusive recommendation.

\section{Materials and methods}

\section{Study area}

The Algeria region is in North African continent, and it is classified as the largest African country covering an area of approximately $2,381,741 \mathrm{~km}^{2}$ (Fig. 1). It extends from the Mediterranean coast in the North until the Sahara Desert in the South. It is bordered to the East by Tunisia and Libya, to the southeast by Niger, to the southwest by Mali, and to the West by Mauritania, Western Sahara, and Morocco. The nation holds a very special spot in the Mediterranean Basin with its geostrategic position and its demographic and economic weight. According with National Office of Statistic (Algeria), more than 43 million of habitants were estimated in 2018 with the higher density mainly concentrated in the North of the country along the Mediterranean coastline. The climatic conditions of the nation could vary considerably from North to South. Specifically, the coastal area has characterized by a Mediterranean climate, while the high plateaus are characterized by hot summers and cold low rainy winters. The Sahara Desert, in the South of the region, instead, represents a true example of extreme climate with very rare rain and strong differences in temperature between day and night. The rainfall regime can be classified as abundant along the coastal zone (North), ranging from 400 to $700 \mathrm{~mm}$ for year, with a substantial increasing precipitation pattern moving from West to East. Precipitations become even more abundant in the northern part of East Algeria, reaching $1200 \mathrm{~mm}$ in some years. The average temperature and humidity during summer range between 21 and $36^{\circ} \mathrm{C}$ and 70 and $90 \%$, respectively. In winter, instead the average temperature and humidity range from 8 to $12{ }^{\circ} \mathrm{C}$ and from 50 to $80 \%$, respectively. Winters are so characterized by not too rigid temperatures but by very high relative 
Table 3 Descriptive statistics for the daily new cases of COVID-19 in 14 cities (In different climates) and the meteorological variables

\begin{tabular}{|c|c|c|c|c|c|}
\hline Variable & $N$ & Mean & Std dev & Minimum & Maximum \\
\hline \multicolumn{6}{|c|}{ Humid to sub-humid region: Algiers } \\
\hline $\operatorname{TMAX}\left({ }^{\circ} \mathrm{C}\right)$ & 153 & 29.30 & 5.01 & 16.5 & 41.8 \\
\hline $\operatorname{TMIN}\left({ }^{\circ} \mathrm{C}\right)$ & 153 & 16.42 & 4.34 & 6.2 & 26.0 \\
\hline RHD (\%) & 153 & 70.36 & 9.63 & 44.0 & 91.0 \\
\hline $\begin{array}{l}\text { Daily new } \\
\text { cases }(N)\end{array}$ & 153 & 30.02 & 24.06 & 0.0 & 116.0 \\
\hline \multicolumn{6}{|c|}{ Humid to sub-humid region: Annaba } \\
\hline $\operatorname{TMAX}\left({ }^{\circ} \mathrm{C}\right)$ & 153 & 27.82 & 5.01 & 16.1 & 42.3 \\
\hline $\operatorname{TMIN}\left({ }^{\circ} \mathrm{C}\right)$ & 153 & 16.19 & 4.10 & 4.0 & 25.2 \\
\hline RHD (\%) & 153 & 75.71 & 8.23 & 52.0 & 92.0 \\
\hline $\begin{array}{c}\text { Daily new } \\
\text { cases }(N)\end{array}$ & 153 & 7.65 & 12.00 & 0.0 & 75.0 \\
\hline \multicolumn{6}{|c|}{ Humid to sub-humid region: Jijel } \\
\hline $\operatorname{TMAX}\left({ }^{\circ} \mathrm{C}\right)$ & 153 & 27.52 & 4.38 & 17.7 & 38.4 \\
\hline $\operatorname{TMIN}\left({ }^{\circ} \mathrm{C}\right)$ & 153 & 17.05 & 4.04 & 6.0 & 25.9 \\
\hline RHD (\%) & 153 & 69.50 & 8.97 & 42.0 & 89.0 \\
\hline $\begin{array}{c}\text { Daily new } \\
\text { cases }(N)\end{array}$ & 153 & 4.51 & 7.21 & 0.0 & 45.0 \\
\hline \multicolumn{6}{|c|}{ Humid to sub-humid region: Oran } \\
\hline $\operatorname{TMAX}\left({ }^{\circ} \mathrm{C}\right)$ & 153 & 28.56 & 5.03 & 17.7 & 38.3 \\
\hline TMIN $\left({ }^{\circ} \mathrm{C}\right)$ & 153 & 17.95 & 4.25 & 6.8 & 26.0 \\
\hline RHD (\%) & 153 & 67.69 & 11.17 & 36.0 & 91.0 \\
\hline $\begin{array}{l}\text { Daily new } \\
\text { cases }(N)\end{array}$ & 153 & 22.76 & 22.46 & 0.0 & 110.0 \\
\hline \multicolumn{6}{|c|}{ Humid to sub-humid region: Blida } \\
\hline $\operatorname{TMAX}\left({ }^{\circ} \mathrm{C}\right)$ & 153 & 29.30 & 5.01 & 16.5 & 41.8 \\
\hline $\operatorname{TMIN}\left({ }^{\circ} \mathrm{C}\right)$ & 153 & 16.42 & 4.34 & 6.2 & 26.0 \\
\hline RHD (\%) & 153 & 70.36 & 9.63 & 44.0 & 91.0 \\
\hline $\begin{array}{l}\text { Daily new } \\
\text { cases }(\mathrm{N})\end{array}$ & 153 & 20.64 & 12.92 & 0.0 & 70.0 \\
\hline \multicolumn{6}{|c|}{ Semi-arid region: Setif } \\
\hline $\operatorname{TMAX}\left({ }^{\circ} \mathrm{C}\right)$ & 153 & 28.95 & 6.72 & 11.2 & 40.8 \\
\hline $\operatorname{TMIN}\left({ }^{\circ} \mathrm{C}\right)$ & 153 & 14.51 & 5.19 & 2.2 & 23.9 \\
\hline RHD (\%) & 153 & 43.78 & 18.03 & 17.0 & 94.0 \\
\hline $\begin{array}{l}\text { Daily new } \\
\text { cases }(N)\end{array}$ & 153 & 19.33 & 18.46 & 0.0 & 102.0 \\
\hline \multicolumn{6}{|c|}{ Semi-arid region: Batna } \\
\hline $\operatorname{TMAX}\left({ }^{\circ} \mathrm{C}\right)$ & 153 & 31.77 & 6.69 & 14.3 & 43.0 \\
\hline TMIN $\left({ }^{\circ} \mathrm{C}\right)$ & 153 & 14.11 & 4.81 & 1.8 & 28.4 \\
\hline RHD (\%) & 153 & 45.55 & 14.90 & 20.0 & 80.0 \\
\hline $\begin{array}{l}\text { Daily new } \\
\text { cases }(N)\end{array}$ & 153 & 9.88 & 14.20 & 0.0 & 70.0 \\
\hline \multicolumn{6}{|c|}{ Semi-arid region: Djelfa } \\
\hline $\operatorname{TMAX}\left({ }^{\circ} \mathrm{C}\right)$ & 153 & 28.53 & 6.98 & 9.8 & 38.7 \\
\hline TMIN $\left({ }^{\circ} \mathrm{C}\right)$ & 153 & 15.71 & 5.25 & 1.8 & 25.7 \\
\hline RHD (\%) & 153 & 36.38 & 17.57 & 14.0 & 91.0 \\
\hline $\begin{array}{l}\text { Daily new } \\
\text { cases }(N)\end{array}$ & 153 & 7.26 & 11.25 & 0.0 & 94.0 \\
\hline \multicolumn{6}{|c|}{ Semi-arid region: Tiaret } \\
\hline $\operatorname{TMAX}\left({ }^{\circ} \mathrm{C}\right)$ & 153 & 30.25 & 7.42 & 10.5 & 41.2 \\
\hline TMIN $\left({ }^{\circ} \mathrm{C}\right)$ & 153 & 13.93 & 5.20 & 1.2 & 23.8 \\
\hline
\end{tabular}


Table 3 (continued)

\begin{tabular}{|c|c|c|c|c|c|}
\hline Variable & $N$ & Mean & Std dev & Minimum & Maximum \\
\hline RHD (\%) & 153 & 45.91 & 22.32 & 16.0 & 99.0 \\
\hline $\begin{array}{l}\text { Daily new } \\
\text { cases }(N)\end{array}$ & 153 & 5.97 & 7.82 & 0.0 & 53.0 \\
\hline \multicolumn{6}{|c|}{ Semi-arid region: Naâma } \\
\hline $\operatorname{TMAX}\left({ }^{\circ} \mathrm{C}\right)$ & 153 & 31.73 & 6.47 & 14.9 & 40.5 \\
\hline $\operatorname{TMIN}\left({ }^{\circ} \mathrm{C}\right)$ & 153 & 17.39 & 5.77 & 3.3 & 28.3 \\
\hline RHD (\%) & 153 & 33.13 & 13.27 & 14.0 & 76.0 \\
\hline $\begin{array}{l}\text { Daily new } \\
\text { cases }(N)\end{array}$ & 153 & 1.66 & 2.86 & 0.0 & 16.0 \\
\hline \multicolumn{6}{|c|}{ Arid region: Ouargla } \\
\hline $\operatorname{TMAX}\left({ }^{\circ} \mathrm{C}\right)$ & 153 & 39.26 & 5.69 & 23.7 & 48.7 \\
\hline TMIN $\left({ }^{\circ} \mathrm{C}\right)$ & 153 & 24.07 & 5.09 & 9.6 & 33.7 \\
\hline RHD (\%) & 153 & 22.39 & 8.65 & 10.0 & 56.0 \\
\hline $\begin{array}{l}\text { Daily new } \\
\text { cases }(N)\end{array}$ & 153 & 7.97 & 9.87 & 0.0 & 53.0 \\
\hline \multicolumn{6}{|c|}{ Arid region: Bechar } \\
\hline $\operatorname{TMAX}\left({ }^{\circ} \mathrm{C}\right)$ & 153 & 35.82 & 5.95 & 21.7 & 43.2 \\
\hline TMIN $\left({ }^{\circ} \mathrm{C}\right)$ & 153 & 23.59 & 5.91 & 10.8 & 35.4 \\
\hline RHD (\%) & 153 & 18.74 & 8.61 & 9.0 & 58.0 \\
\hline $\begin{array}{l}\text { Daily new } \\
\text { cases }(N)\end{array}$ & 153 & 2.27 & 4.62 & 0.0 & 28.0 \\
\hline \multicolumn{6}{|c|}{ Hyper-arid region: Tamanrasset } \\
\hline $\operatorname{TMAX}\left({ }^{\circ} \mathrm{C}\right)$ & 153 & 35.83 & 1.86 & 29.4 & 40.7 \\
\hline TMIN $\left({ }^{\circ} \mathrm{C}\right)$ & 153 & 22.29 & 3.30 & 12.0 & 29.4 \\
\hline RHD (\%) & 153 & 17.54 & 10.00 & 8.0 & 68.0 \\
\hline $\begin{array}{l}\text { Daily new } \\
\text { cases }(N)\end{array}$ & 153 & 1.29 & 3.13 & 0.0 & 18.0 \\
\hline \multicolumn{6}{|c|}{ Hyper-arid region: Adrar } \\
\hline $\operatorname{TMAX}\left({ }^{\circ} \mathrm{C}\right)$ & 153 & 41.69 & 5.40 & 22.0 & 48.4 \\
\hline TMIN $\left({ }^{\circ} \mathrm{C}\right)$ & 153 & 25.36 & 5.48 & 8.0 & 35.0 \\
\hline RHD (\%) & 153 & 16.38 & 8.04 & 8.0 & 69.0 \\
\hline $\begin{array}{c}\text { Daily new } \\
\text { cases }(N)\end{array}$ & 153 & 4.07 & 6.30 & 0.0 & 34.0 \\
\hline
\end{tabular}

humidity. In the high plateaus, the yearly rainfall substantially decreases ranging among $100 \mathrm{~m}$ and $400 \mathrm{~mm}$, mainly occurring during the months of October and December. The average maximum and minimum temperatures in winter are $16{ }^{\circ} \mathrm{C}$ and $-2{ }^{\circ} \mathrm{C}$, respectively, with sporadic snowfall on the highest peaks, while during summer, they are $42{ }^{\circ} \mathrm{C}$ and $10{ }^{\circ} \mathrm{C}$, respectively. The relative humidity is moderate, varying from 30 to $60 \%$ in summer and from 60 to $80 \%$ in winter. In the Algerian Sahara's desert, the climate is classified as extremely arid to hyper-arid with the almost entirely absence of rainfall during the year, except for torrential rains. In this area, a significant difference in temperature between the day and the night also occurs. In winter, during the day, the temperature ranges from 20 to $30{ }^{\circ} \mathrm{C}$ with cold nights $(-5$ to $10^{\circ} \mathrm{C}$ ). In summer, instead the temperature can reach $47^{\circ} \mathrm{C}$ during the day and $30^{\circ} \mathrm{C}$ at the night. The relative humidity is low during all the year (less than 40\%). Fourteen Algerian cities have been selected in different climatic regimes for this study, including (i) Algiers, Annaba, Jijel, Oran, and Blida in humid to sub-humid climate; (ii) Setif, Batna, Djelfa, Tiaret, and Naâma in semi-arid climate, (iii) Ouargla and Bechar in arid climate; and (iv) Tamanrasset and Adrar in hyper-arid climate (Fig. 1). The location of all cities center is reported in Table 1.

\section{Data collection}

Data of COVID-19 daily new cases were collected considering the fourteen Algerian cities from April 1, 2020, to August 31, 2020. The data was made available from the Algerian Ministry of Health (http://covid19.sante.gov.dz/ carte/\#pll_switcher). 

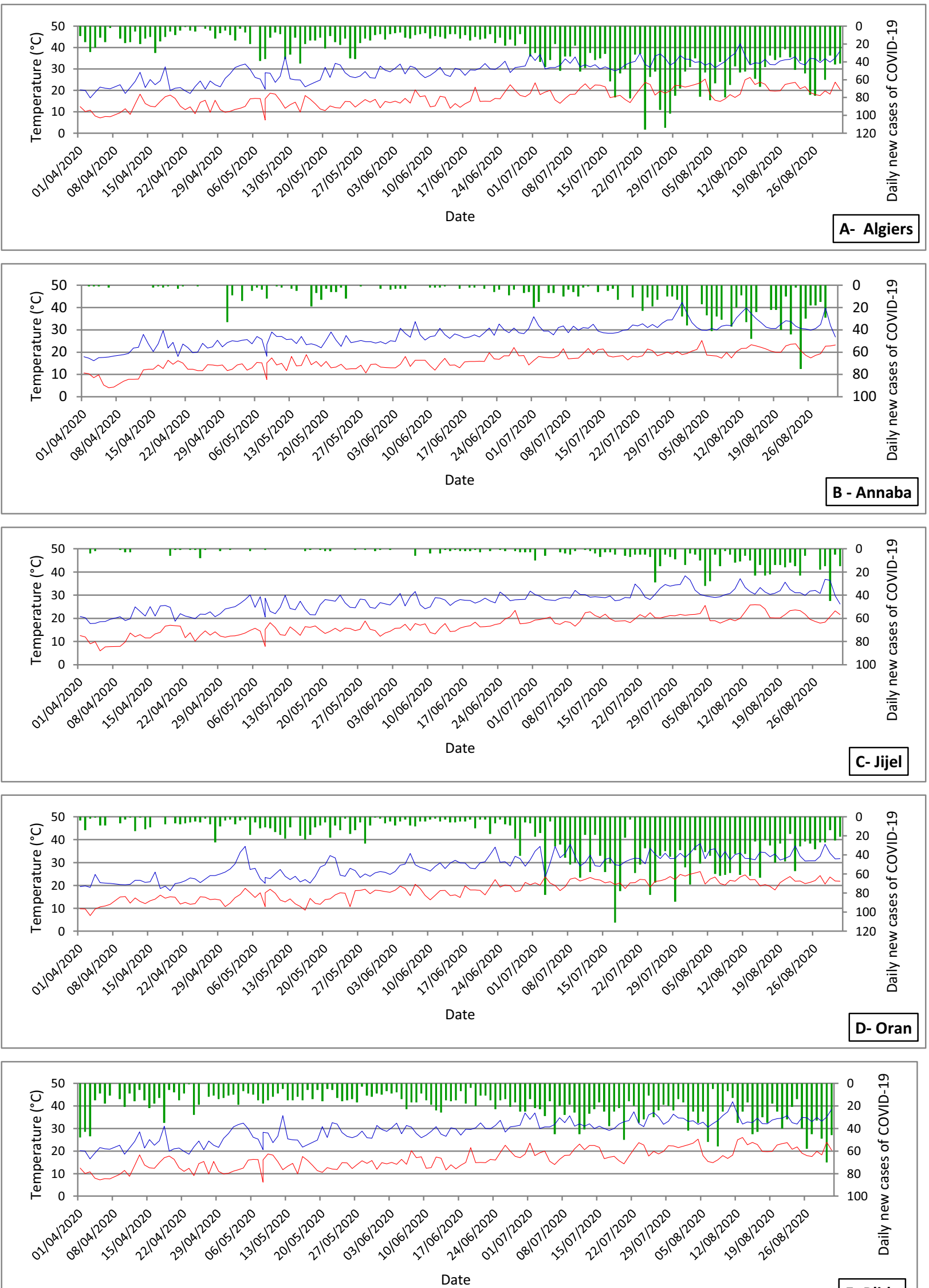

E- Blida 
४Fig. 2 Variation of daily TMIN, TMAX, and new cases of COVID-19 in the humid to sub-humid regions (5 Algerian cities) (period: April 1, 2020, to August 31, 2020). Green, daily new cases of COVID-19; blue, TMAX; red, TMIN

To correlate the COVID-19 case with meteorological condition, a representative weather station was chosen for each city. The geographic characteristics of all the weather stations are reported in Table 2. The daily meteorological data, including maximum temperature (TMAX) $\left({ }^{\circ} \mathrm{C}\right)$, minimum temperature (TMIN) $\left({ }^{\circ} \mathrm{C}\right)$, and relative humidity (RHD) (\%), were obtained from the National Weather Center (ONM) (https://www.meteo.dz/previsions/carte).

\section{Data analysis}

The effect of meteorological factors such as wind speed, temperature, sunshine hours, rainfall, and humidity on COVID-19 cases was usually examined using the Spearman correlation test (Rendana 2020), Pearson correlation, Kendall's rank correlation (Doğan et al. 2020; Shahzad et al. 2021), autoregressive distributed lag (ARDL) (Doğan et al. 2020), and linear regression method. Specifically, in this study, a linear regression method was utilized to investigate the interconnection among new cases of COVID-19 and the available factors.

First, a descriptive statistical of epidemiological data (daily new cases of COVID-19) along with daily meteorological factors during the period April 1, 2020-August 31, 2020, in the fourteen Algerian cities was also performed. Secondly, given the spatial and temporal variability of climate characteristics, the linear regression method was used to explore the relationship among daily meteorological factors and correspondent new cases of COVID-19. The number of daily new cases was chosen as dependent variables, while the daily meteorological factors were selected as independent variables. The formula used was as follows:

$\left.Y=\alpha+\beta_{1} X_{1}+\beta_{2} X_{2}+\cdots+\beta_{n} X_{n} 1\right)$

where $Y$ is the linear function indicating a set of predictor variables, $\alpha$ indicates a numerical constant that represents an intercept, $n$ is the number of predictor variables, $X$ represents those meteorological factors that are significantly associated with epidemiological data, and finally $\beta$ is the regression coefficients of $X$. Each $\beta$ reflects how $Y$ will change with the $X$, which is associated with the $\beta$, when all other $X$ variables are constant (Jaccard et al. 2006). This analysis was performed in Origin Pro 2019b software.

Based on the statement of the World Health Organization (WHO) which reported an incubation period for COVID-19 between 2 and 10 days with a mean incubation period of 5.2 days (WHO 2020), 5 days lag time to assess the correlation between the new cases of COVID-19 and climate's factor variability has been considered (temperature and relative humidity).

\section{Results}

\section{Description analysis}

The descriptive statistics computed for the daily new cases of COVID-19 along with climate characteristics of temperature and humidity during the study period (April 1, 2020, to August 31,2020) is shown in Table 3. According to the data, in humid to sub-humid regions, the daily new cases of COVID-19 ranged from a minimum of 0 in all cities to a maximum of 116 registered in the city of Algiers. The daily TMIN and TMAX vary from $4.0^{\circ} \mathrm{C}$ in Annaba to $26.0^{\circ} \mathrm{C}$ in Algiers and Blida and $16.1{ }^{\circ} \mathrm{C}$ in Algiers to $42.3{ }^{\circ} \mathrm{C}$ in Annaba, respectively. The RHD ranged between $36 \%$ in Oran to $92 \%$ in Annaba. In the semi-arid regions, the daily new cases of COVID-19 ranged from 0 (in all cities) to 102 (Setif). The daily TMIN and TMX ranged from $1.2{ }^{\circ} \mathrm{C}$ in Tiaret to $28.4{ }^{\circ} \mathrm{C}$ in Batna and $9.8{ }^{\circ} \mathrm{C}$ in Djelfa to $43.0^{\circ} \mathrm{C}$ in Batna, respectively. The daily RHD varies between $14 \%$ in Djelfa and 99\% in Tiaret. In the arid regions, instead, the daily new cases of COVID-19 ranged from 0 to 53 (Ouargla). Here the TMIN and TMAX vary from $9.6{ }^{\circ} \mathrm{C}$ in Ouargla to $35.4{ }^{\circ} \mathrm{C}$ in Bechar and $21.7^{\circ} \mathrm{C}$ in Bechar to $48.7{ }^{\circ} \mathrm{C}$ in Ouargla, respectively. The daily RHD ranged from 9 to $58 \%$ in Bechar. Finally, in the hyper-arid regions, the daily new cases of COVID-19 varied between 0 and 34 in Adrar. In this climatic zone, the TMIN and TMAX ranged from 8.0 to $35.0{ }^{\circ} \mathrm{C}$ and 22.0 to $48.4{ }^{\circ} \mathrm{C}$, respectively, in Adrar. The daily RHD ranged from 8 to $69 \%$ in Adrar.

\section{Effects of daily minimum and maximum temperatures and daily relative humidity on daily new cases of COVID-19}

As previously described, the selected fourteen Algerian cities are characterized by different climatic conditions. The figures below show the effect of temperature on daily new cases of COVID-19, in these different cities and climates, during the 5-month period (April 1, 2020, to August 31, 2020).

In the humid to sub-humid regions (Figs. 2 and 3), the number of daily new cases ranged between 0 and 116 .

- In Algiers the daily new cases of COVID-19 ranged between 0 and 116 for 3,615,149 inhabitants. The minimum number of daily new cases ( 0 cases) was observed on April 20, 2020, where the daily TMIN and TMAX were $14.4{ }^{\circ} \mathrm{C}$ and $24.4{ }^{\circ} \mathrm{C}$, respectively, with a RHD of the $83 \%$. However, the highest number of daily cases (116 cases) was observed on July 23,2020 , with a TMIN, TMAX, and RHD of $23.7^{\circ} \mathrm{C}, 32.1^{\circ} \mathrm{C}$, and $70 \%$, respectively. 

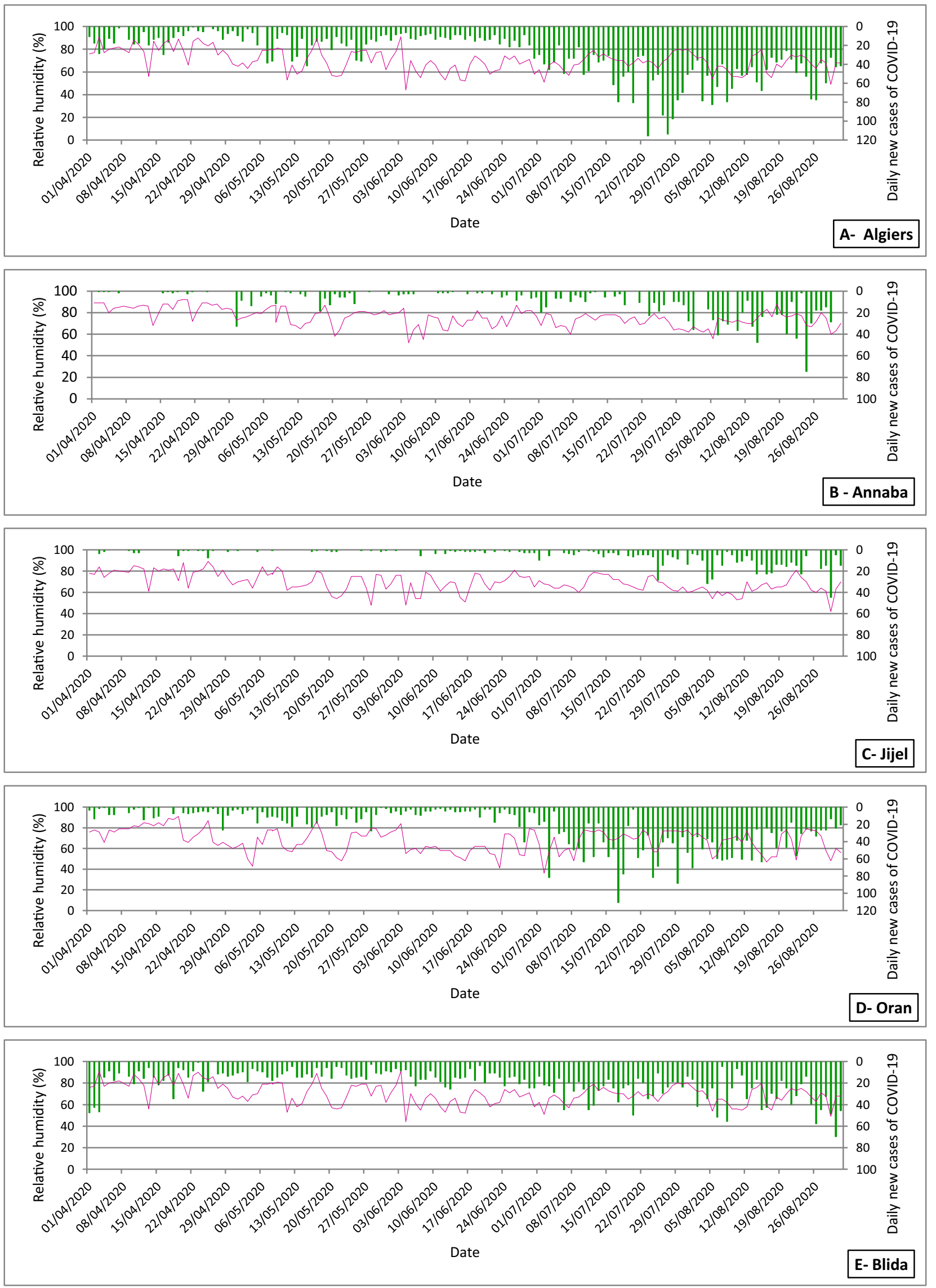
4 Fig. 3 Variation of daily RHD and daily new cases of COVID-19 in the humid to sub-humid regions (5 Algerian cities) (period: April 1, 2020, to August 31, 2020). Green, daily new cases of COVID-19; pink, RHD

- In Annaba the daily new cases of COVID-19 ranged from 0 to 75 for 695,003 inhabitants. This city registered several days (55) with no confirmed cases of COVID-19. In this period, the daily TMIN and TMAX ranged from 4.3 to $23.2^{\circ} \mathrm{C}$ and from 17.6 to $33.7^{\circ} \mathrm{C}$, respectively. The daily RHD ranged from 55 to $92 \%$. The highest report of daily new cases instead ( 75 confirmed cases) was observed on August 24, 2020, when TMIN and TMAS were $20.7^{\circ} \mathrm{C}$ and $30.6{ }^{\circ} \mathrm{C}$, respectively with a daily RHD of $68 \%$.

- In Jijel the daily new cases of COVID-19 varied from 0 to 45 for 726,303 inhabitants. Also in these cases, several days (54) during the studied period registered no cases of COVID-19. The range of daily TMIN and TMAX was from 6.0 to $21.7{ }^{\circ} \mathrm{C}$ and 18.6 to $34.6{ }^{\circ} \mathrm{C}$, respectively, while the daily RHD varied from 54 to $84 \%$, whereas the number of maximum daily new cases ( 45 cases) was observed on August 29, 2020, with a daily TMIN and TMAX of $20.7^{\circ} \mathrm{C}$ and $36.4^{\circ} \mathrm{C}$, respectively. In addition, the daily RHD was $42 \%$.

- In Oran the daily new cases of COVID-19 ranged from 0 to 111 for $1,822,544$ inhabitants. The minimum value of daily new cases ( 0 cases) was observed in some days of April and May. In these 2 months, the daily TMIN and TMAX varied from 11.8 to $15.0^{\circ} \mathrm{C}$ and 17.7 to $24.0^{\circ} \mathrm{C}$, respectively, while the daily RHD ranged from 64 to $91 \%$. However, the maximum number (111 cases) was observed on July 17, 2020, where the daily TMIN and TMAX were $20.4{ }^{\circ} \mathrm{C}$ and $29.0{ }^{\circ} \mathrm{C}$, respectively, with a daily RHD of $70 \%$.

- In Blida the daily new recorded cases of COVID-19 varied between 0 and 70 considering 1,348,839 inhabitants. The minimum report of daily new cases ( 0 cases) was observed in only 1 day of April 26, 2020, where the daily TMIN and TMAX were $15.4{ }^{\circ} \mathrm{C}$ and $20.6{ }^{\circ} \mathrm{C}$, respectively, with a RHD of $86 \%$. In addition, the higher number of daily new cases (70 cases) was reported on August 30, 2020, where the daily TMIN, TMAX, and RHD were $23.9^{\circ} \mathrm{C}, 35.1^{\circ} \mathrm{C}$, and $68 \%$, respectively.

In the semi-arid regions (Figs. 4 and 5), the number of daily new cases ranged from 0 to 102 .

- In Setif the daily new infected of COVID-19 ranged among 0 and 102 for 1,531,274 inhabitants. The lowest value of daily new cases ( 0 cases) was observed in a few days (6) of April and May. The daily TMIN and TMAX varied from 9.4 to $22.3{ }^{\circ} \mathrm{C}$ and 17.8 to $35.0{ }^{\circ} \mathrm{C}$, respectively, with a RHD ranging from 21 to $82 \%$. However, the maximum number of daily new cases
(102 cases) was observed on July 16, 2020, when the daily TMIN and TMAX were $17.7{ }^{\circ} \mathrm{C}$ and $31.2{ }^{\circ} \mathrm{C}$, respectively, with a RHD of $63 \%$.

- In Batna the daily new cases of COVID-19 ranged from 0 to 70 for about $1,354,757$ inhabitants. The lowest value of daily new cases ( 0 cases) was observed in some few days (34) during the analyzed period. Accordingly, the daily TMIN and TMAX ranged from 1.8 to $21.9^{\circ} \mathrm{C}$ and 14.3 to $40.3{ }^{\circ} \mathrm{C}$, respectively, with a daily RHD ranging from 21 to $80 \%$. The maximum number of daily new cases ( 70 cases) instead was observed on July11, 2020, with daily TMIN and TMAX of $17.2{ }^{\circ} \mathrm{C}$ and $40.3{ }^{\circ} \mathrm{C}$, respectively. The daily RHD for the same day was $25 \%$.

- In Djelfa the daily new cases of COVID-19 ranged between 0 and 94 for 1,434,840 inhabitants. The lower number of daily new cases ( 0 cases) was observed in some days (24), with a daily TMIN, TMAX, and RHD ranging from 1.8 to $23.7^{\circ} \mathrm{C}, 12.5$ to $35.8^{\circ} \mathrm{C}$, and 19 to $91 \%$, respectively, whereas the higher number of new cases (94 cases) was observed on July 21,2020 , with a daily TMIN and TMAX of $19.7^{\circ} \mathrm{C}$ and $32.6{ }^{\circ} \mathrm{C}$, respectively. The daily RHD was $94 \%$.

- In Tiaret the daily report of COVID-19 ranged from 0 to 53 for 1,024,512 inhabitants. The minimum number of daily new cases ( 0 cases) was observed during several days (37) in the 5 months. The daily TMIN and TMAX in those days varied from 1.2 to $22.8^{\circ} \mathrm{C}$ and 14.0 to $36.7^{\circ} \mathrm{C}$, respectively, while the daily RHD ranged from 23 to $98 \%$. However, the maximum report of daily new cases (53 cases) was observed on July 21, 2020, where the daily TMIN and TMAX were $21.0^{\circ} \mathrm{C}$ and $36.7^{\circ} \mathrm{C}$ respectively, with a daily RHD of $23 \%$.

- In Naâma the daily new cases of COVID-19 ranged between 0 and 16 for about 319,686 inhabitants. The minimum number of daily new cases (0 cases) was observed during several days (81) of the study period (5 months), where the daily TMIN and TMAX ranged from 3.3 to $25.4{ }^{\circ} \mathrm{C}$ and 17.4 to $39.7{ }^{\circ} \mathrm{C}$, respectively, and the daily RHD varied from 17 to $76 \%$. The maximum number of daily new cases instead (16 cases) was registered on July 20, 2020, where the daily TMIN, TMAX, and RHD were $21.8{ }^{\circ} \mathrm{C}, 35.1^{\circ} \mathrm{C}$, and $37 \%$, respectively.

In the arid and hyper-arid regions (Figs. 6, 7, 8, and 9), the number of daily new cases varies between 0 and 53 .

- In Ouargla the daily new cases of COVID-19 ranged from 0 to 53 for 733,797 inhabitants. The minimum report of daily new cases ( 0 cases) was observed during several days (32) of the study period (5 months). The daily TMIN, TMAX, and RHD in this period ranged from 9.6 to $31.6{ }^{\circ} \mathrm{C}$ and 23.7 to $47.9^{\circ} \mathrm{C}$ and 11 to $48 \%$, respectively. The highest number of daily new infected (53 cases) was observed on August 1, 2020, where the 

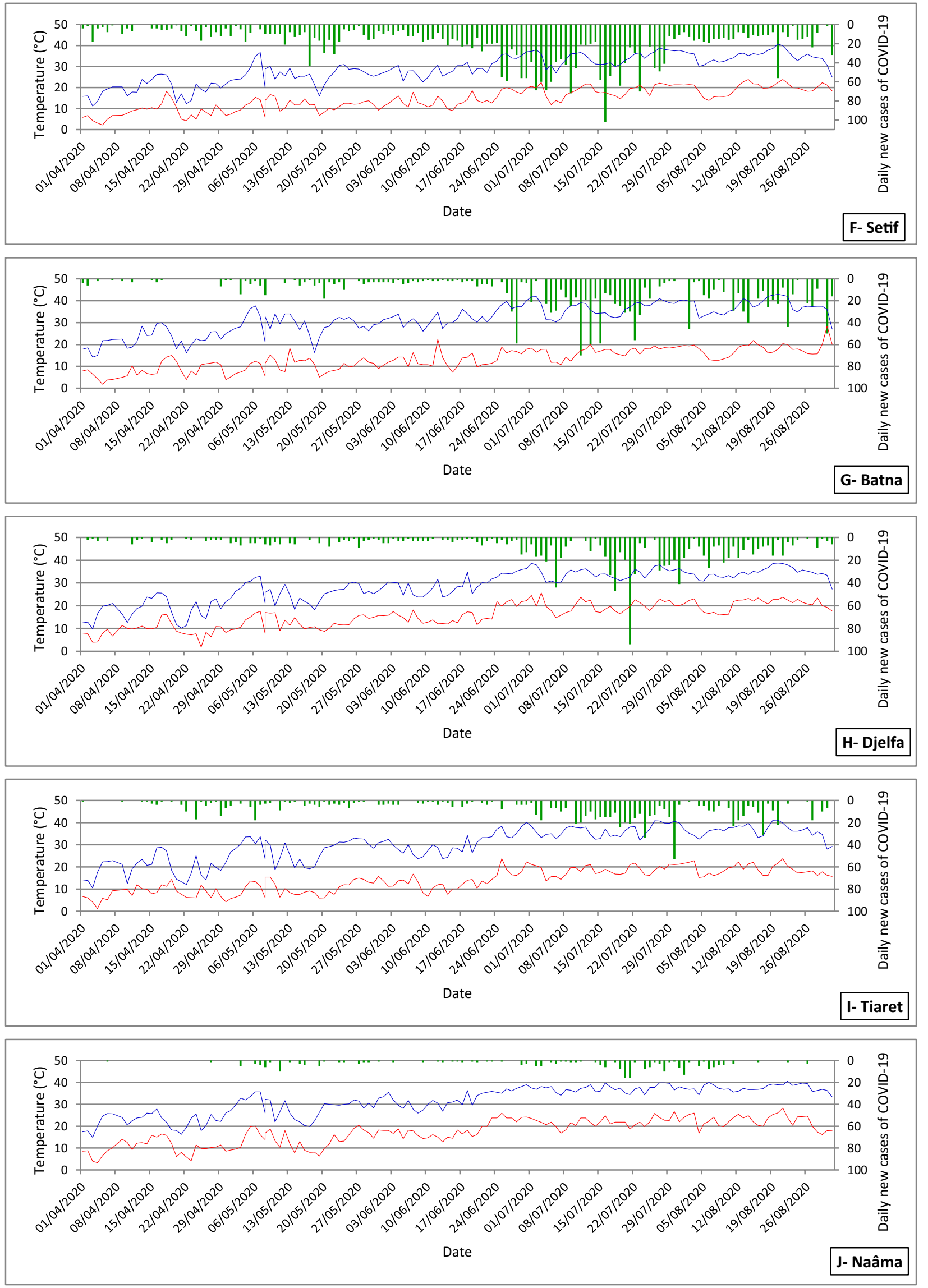
4Fig. 4 Variation of daily TMIN, TMAX, and new cases of COVID19 in the semi-arid regions (5 Algerian cities) (period: April 1, 2020, to August 31, 2020). Green, daily new cases of COVID-19; blue, TMAX; red, TMIN

daily TMIN and TMAX were $22.6{ }^{\circ} \mathrm{C}$ and $43.1{ }^{\circ} \mathrm{C}$, respectively, with a RHD of $17 \%$.

- In Bechar the daily new cases of COVID-19 ranged between 0 and 28 for 338,495 inhabitants. The minimum number of daily new cases ( 0 cases) was observed during several days (90) of the study period (5 months), with a daily TMIN, TMAX, and RHD ranging from 10.8 to $33.6{ }^{\circ} \mathrm{C}, 22.6$ to $43.1^{\circ} \mathrm{C}$, and 10 to $50 \%$, respectively, whereas the maximum daily new infected ( 28 cases) was observed on May 26, 2020, with a daily TMIN and TMAX of $25.0^{\circ} \mathrm{C}$ and $35.3{ }^{\circ} \mathrm{C}$, respectively. In addition, the daily RHD was $17 \%$.

- In Tamanrasset the daily new cases of COVID-19 ranged from 0 to 18 for 240,353 inhabitants. The minimum number of daily new cases ( 0 cases) was observed during several days (110) of the study period (5 months). The daily TMIN and TMAX in those days varied from 12.0 to $26.6{ }^{\circ} \mathrm{C}$ and 30.0 to $39.2{ }^{\circ} \mathrm{C}$, respectively, while the daily RHD ranged from 8 to $61 \%$. However, the higher number of daily new cases (18 cases) was observed on July 25, 2020, where the daily TMIN and TMAX were $25.7^{\circ} \mathrm{C}$ and $34.9^{\circ} \mathrm{C}$ with a daily RHD of $43 \%$.

- In Adrar the daily new cases of COVID-19 ranged between 0 and 34 for 543,898 inhabitants. The minimum daily new cases ( 0 cases) were observed during several days (61) of the study period (5 months), where the daily TMIN and TMAX ranged from 12.1 and $33.9^{\circ} \mathrm{C}$ and between 30.0 and $46.3{ }^{\circ} \mathrm{C}$ respectively, while the daily RHD varied from 9 to $60 \%$. The higher number of daily new cases (34 cases) was observed on August 9, 2020, where the daily TMIN, TMAX, and RHD were $28.0^{\circ} \mathrm{C}$, $42.4{ }^{\circ} \mathrm{C}$, and $18 \%$, respectively.

After a first preliminary analysis, the results, considering the reported case in the investigated city, showed a very weak effect of temperature and relative humidity on daily new cases of COVID-19 that are not dependent from these climatic parameters.

\section{Correlations between daily TMIN, TMAX, RHD, and daily new cases of COVID-19}

Several scatter diagrams were realized to highlight the absence/presence of linear correlation among the considered meteorological factors and daily new cases of COVID19 in the fourteen Algerian cities, during a study period of 5 months (April 1, 2020, to August 31, 2020). They are shown in Fig. 10 for sub-humid to humid regions (5 Algerian cities), Fig. 11 for semi-arid regions (5 Algerian cities), Fig. 12 for arid regions (2 Algerian cities), and Fig. 13 for hyper-arid regions (2 Algerian cities). From a first analysis of these diagrams, an inconsistent correlation between daily new cases of COVID-19 and meteorological data (TMIN, TMAX, and RHD) was found in the 14 Algerian cities (the correlation was extremely weak). Figures $12,15,18$, and 21 show a decreasing linear trend of daily relative humidity (RHD) as a function of new cases of COVID-19 but with a weak negative correlation. Conversely, the temperature parameter representation (Figs. 10, 11, 13, 14, 16, 17, 19, and 20) show an increasing linear trend as a function of new cases of COVID-19 but always with a weak positive correlation. However, the linear regression equations and the correlation coefficients $(R)$ for each parameter are presented in Table 4. In the humid to sub-humid regions (Figs. 10, 11,12 , and Table 4), the correlation coefficients $(R)$ among daily TMIN, TMAX, and RHD with the number of daily new cases of COVID-19 ranged from 0.391 to $0.498,0.332$ to 0.490 , and 0.105 to 0.324 , respectively. In the semi-arid regions instead (Figs. 13, 14, 15, and Table 4), the correlation coefficients $(R)$ among daily TMIN, TMAX, and RHD with the number of daily new cases of COVID-19 varied between 0.212 to $0.447,0.274$ to 0.423 , and 0.167 to 0.316 , respectively. Analyzing the arid regions (Figs. 16, 17, 18, and Table 4), the correlation coefficients $(R)$ between daily TMIN, TMAX, and RHD with the number of daily new cases of COVID-19 ranged from 0.100 to $0.356,0.173$ to 0.351 , and 0.032 to 0.272 , respectively, Finally, in the hyperarid regions (Figs. 19, 20, 21, and Table 4), the correlation coefficients $(R)$ between daily TMIN, TMAX, and RHD with the number of daily new cases of COVID-19 ranged from 0.161 to $0.182,0.182$ to 0.217 , and 0.100 to 0.110 , respectively. Therefore, the results of the linear regression model further confirmed the weak correlation between meteorological data (weak negative correlation for RHD and weak positive correlation for temperature) and daily new cases of COVID-19 for the 14 considered Algerian cities. 

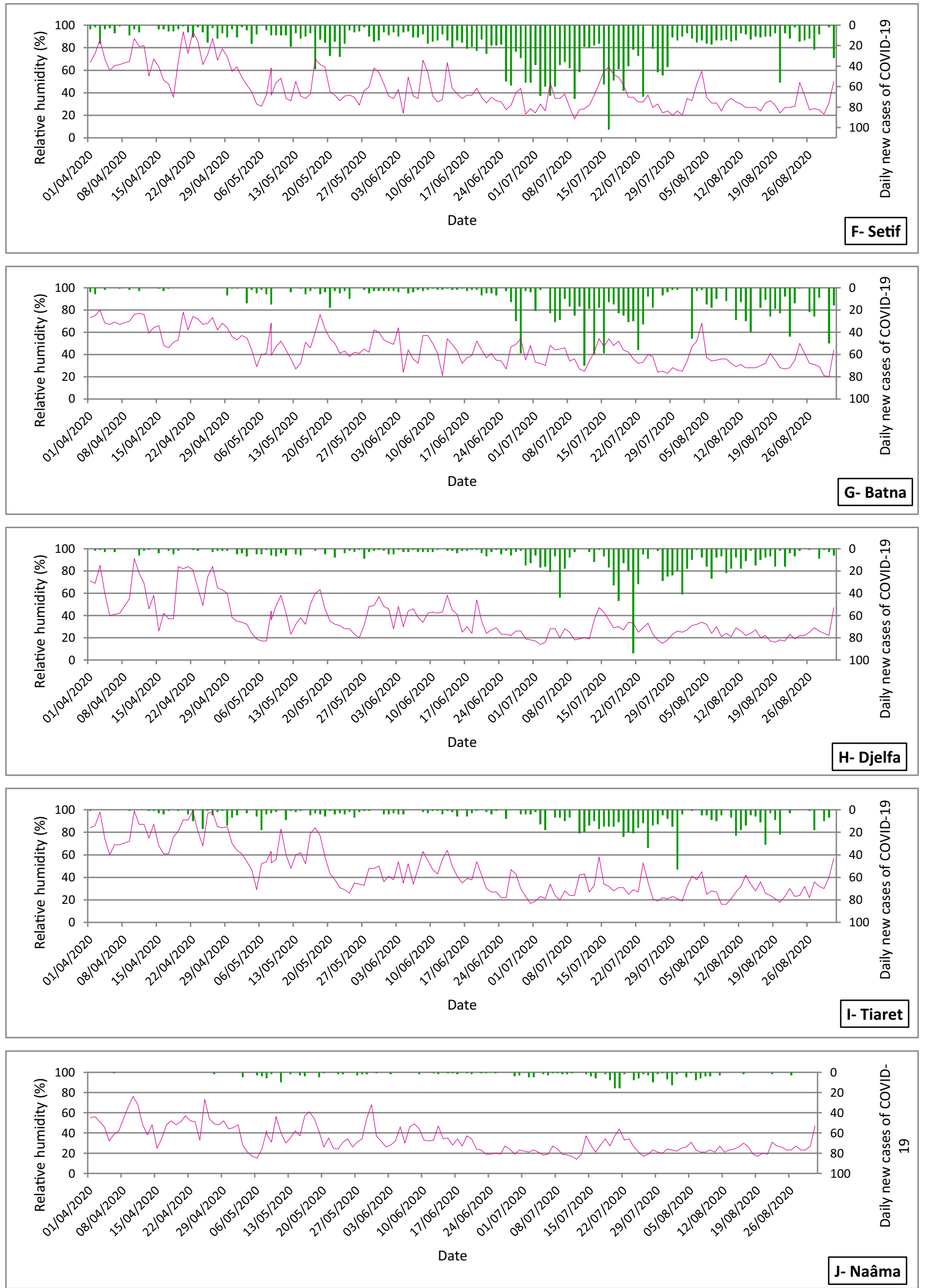
4Fig. 5 Variation of daily RHD and daily new cases of COVID-19 in the semi-arid regions (5 Algerian cities) (period: April 1, 2020, to August 31, 2020). Green, daily new cases of COVID-19; pink, RHD

\section{Discussions}

Today, the COVID-19 pandemic is the definitive global health crisis of our time and the greatest challenge facing by the world community (United Nations Development Program 2020). In this study, the relationship among few meteorological factors (TMIN, TMAX, and RHD) and daily new cases of COVID-19 in different climates across some regions in Algeria (North Africa) has been estimated and discussed. The obtained results stated a weak correlation among COVID-19's new cases and meteorological factors (temperature and relative humidity). The results also agree with the previous study investigation conducted by Prata et al. (2020) who showed how COVID-19 may not vanish at high temperatures, for example, during the period from 15 to 31 July 2020. Conversely, other studies (Zhu and Xie 2020; Wang et al. 2020a, b; Yongjiana et al. 2020; NúñezDelgado 2020; Liu et al. 2020; Moriyama and Ichinohe 2019; Xu et al. 2020) observed how high temperatures could be beneficial to the disappearance of COVID-19, while low humidity environments could favor the transmission of COVID-19 (Sun et al. 2020; Kudo et al. 2019; Wu et al 2020). For example, Auler et al. (2020) highlighted how the COVID-19 transmission rate in Brazil was initially favored by the high mean temperatures $\left(27.5^{\circ} \mathrm{C}\right)$ and intermediate relative humidity (near $80 \%$ ). Generally, the infectious diseases such as the Severe Acute Respiratory Syndrome (SARS) and the influenza are strongly influenced by the low values of temperature and high values of humidity (Davis et al. 2016a, b) and how the transmission of pandemic influenza virus is favored under cold, dry conditions (Steel et al. 2011) this seems not be the cases of COVID-19. Summarizing in this study, we concluded that the COVID-19 could fit to both high or low temperatures and how it seems to not significatively vanish if the climate is wet or dry (high or low humidity). Despite this assumption, it is worth to mention that the higher $R$, especially for TMIN $(R=0.498)$ and TMAX $(R=0.490)$, correlations were observed in humid-sub humid and semi-arid regions. These regions are characterized by the higher population amount and density (in Algiers, Oran, and Setif cities where the density is 3,037; 862 and 385 people per square kilometer, respectively) that probably could affect more than climate characteristics of COVID-19 spread.

Accordingly, with this assumption, here two more examples in two cities with different climates around the world are reported (from October 1 to 10, 2020). In the city of Moscow (Russia), the daily new cases of COVID-19 ranged from 2,424 to 4,082 where the daily TMIN and TMAX vary from 4.9 to $13.6{ }^{\circ} \mathrm{C}$ and 12.6 to $18.7{ }^{\circ} \mathrm{C}$, respectively, and the RHD ranged from 42 to $84 \%$. In Texas (USA), instead, the daily new cases of COVID-19 varied between 2,199 and 4,577. In the city, the daily TMIN and TMAX ranged from 11.9 to $20.2{ }^{\circ} \mathrm{C}$ and 27.3 to $37.9^{\circ} \mathrm{C}$, respectively, and the RHD ranged from 42 to $69 \%$.

A further investigation focusing on the fluctuations in environmental pollutants and air quality before, during, and after each COVID-19 wave along with the study of the development trend in the same cities after vaccination of $70 \%$ of the country's inhabitants (according to the WHO recommendations) could give new insight to the research.

\section{Conclusion}

To determine the correct position on the current debate on impact of temperature and humidity on the viral spread of COVID-19, this study aimed to investigate the effects of these two parameters on the daily new cases of COVID-19 in 14 Algerian cities (North Africa) characterized by different climatic conditions (humid to sub-humid, semi-arid, arid to hyper-arid) from April to August 2020.

The findings showed that the daily new cases of COVID19 pandemic, in cities with different climates, were not influenced by the increase or decrease in temperature or humidity, i.e., the effects of temperature and humidity on COVID-19 transmission are weak. The linear regression equations and the correlation coefficients $(R)$ show a weak correlation between meteorological factors (temperature and relative humidity) and daily new cases of COVID-19. The correlation coefficients $(R)$ between daily TMIN, TMAX, and RHD with the number of daily new cases of COVID19 ranged from 0.100 to $0.498,0.173$ to 0.490 , and 0.032 to 0.324 , respectively. It should be noted that the higher $R$, especially for TMIN $(R=0.498)$ and TMAX $(R=0.490)$ correlations were observed in humid-sub humid and semi-arid regions. These regions are characterized by the higher population amount and density that probably could affect more than climate characteristics of COVID-19 spread.

Today, COVID-19 continues to spread globally, and the fourth wave of COVID-19 has been observed. The World Health Organization says that the COVID-19 pandemic is one big wave, not seasonal. It is now clear that this virus did not behave like influenza which tended to follow seasonal trends. The world was waiting for COVID-19 to fade with the rise in temperature or the decrease in humidity, but the latter adapted to the environment due to its genetic components "A.A.R.N," which made it difficult to detect a vaccine quickly. 

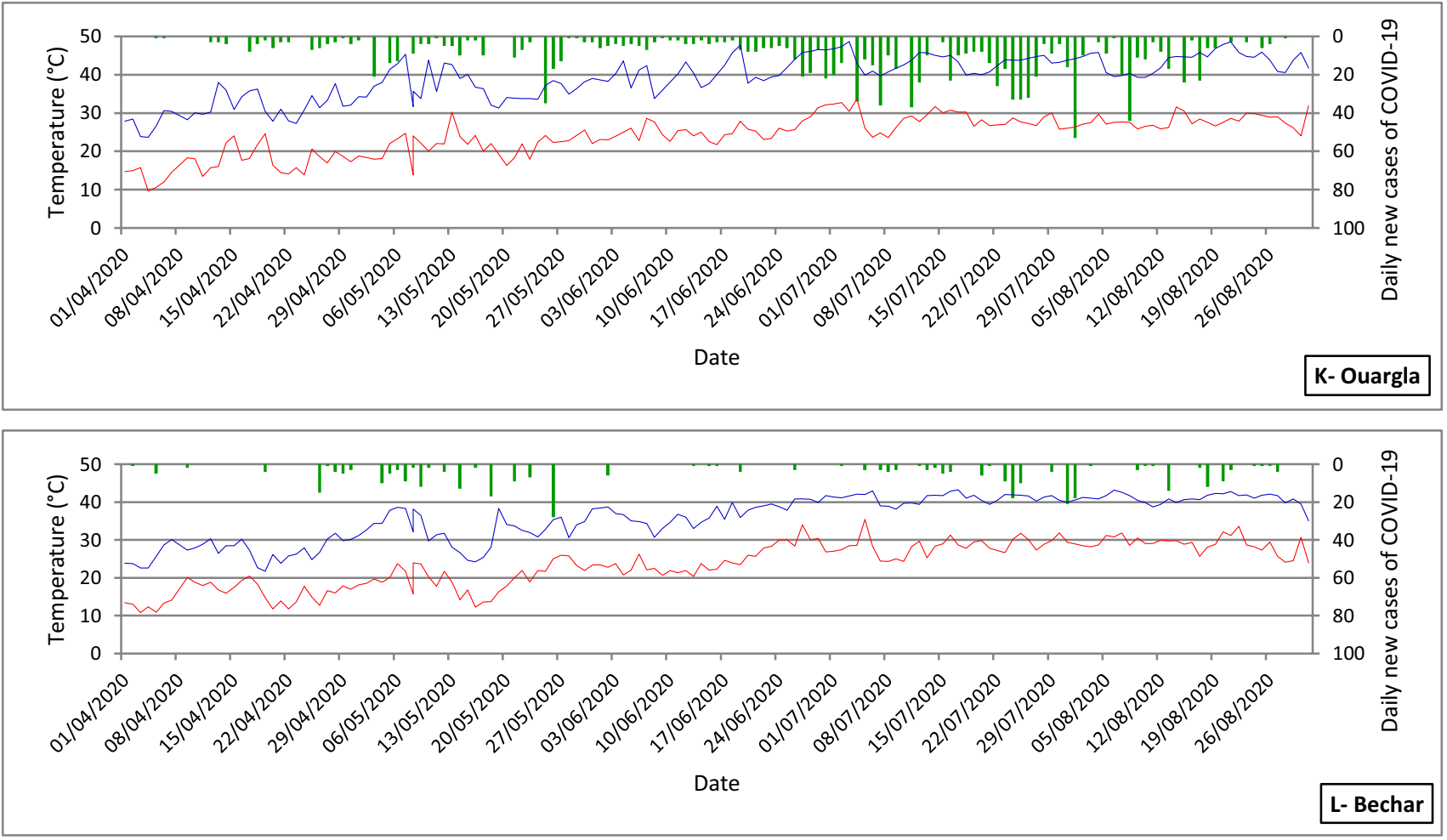

Fig. 6 Variation of daily TMIN, TMAX, and new cases of COVID-19 in the arid regions (2 Algerian cities) (period: April 1, 2020, to August 31, 2020). Green, daily new cases of COVID-19; blue, TMAX; red, TMIN

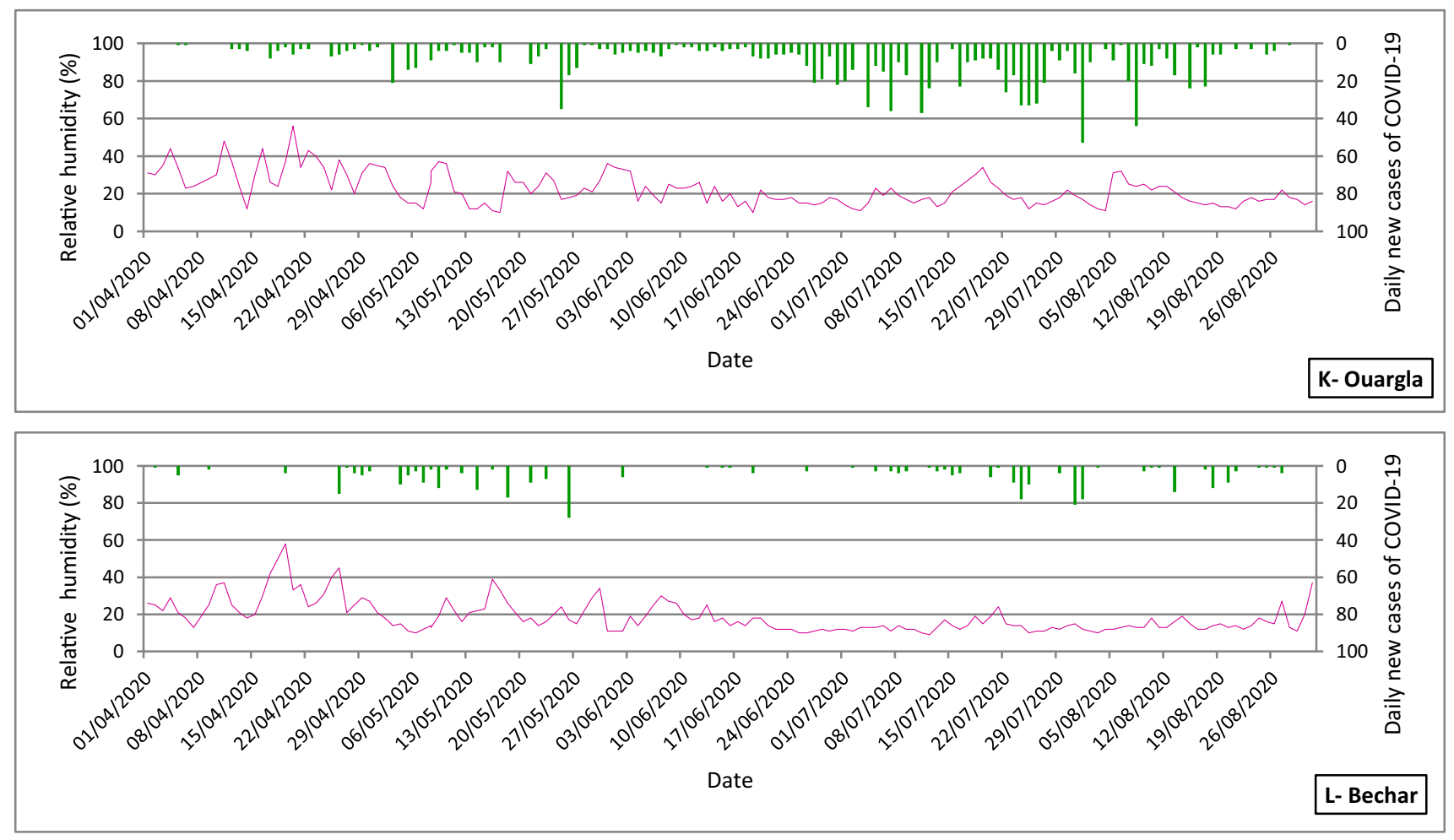

Fig. 7 Variation of daily RHD and daily new cases of COVID-19 in the arid regions (2 Algerian cities) (period: April 1, 2020, to August 31, 2020). Green, daily new cases of COVID-19; pink, RHD 


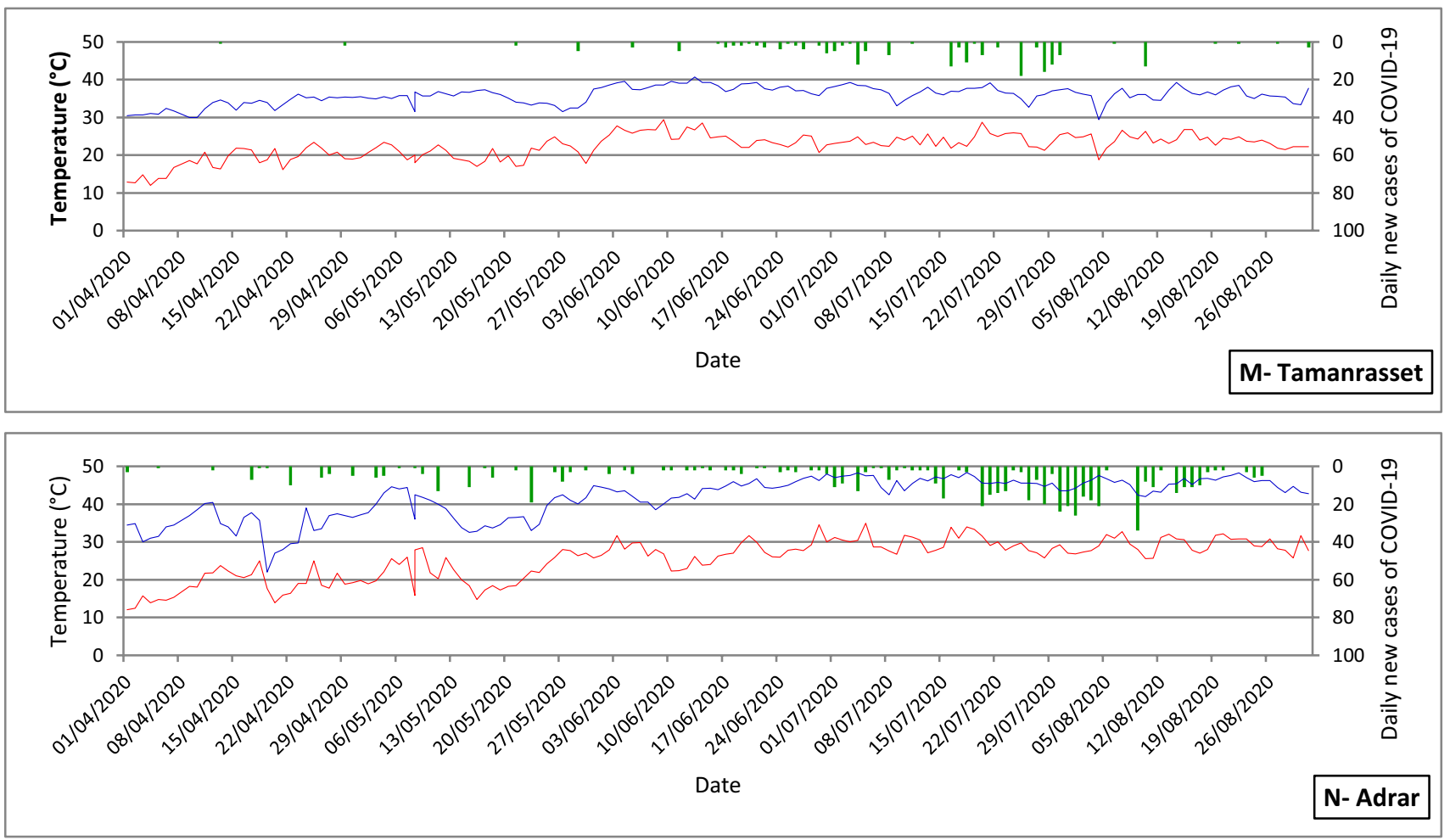

Fig. 8 Variation of daily TMIN, TMAX, and new cases of COVID-19 in the hyper-arid regions (2 Algerian cities) (period: April 1, 2020, to August 31, 2020). Green, daily new cases of COVID-19; blue, TMAX; red, TMIN

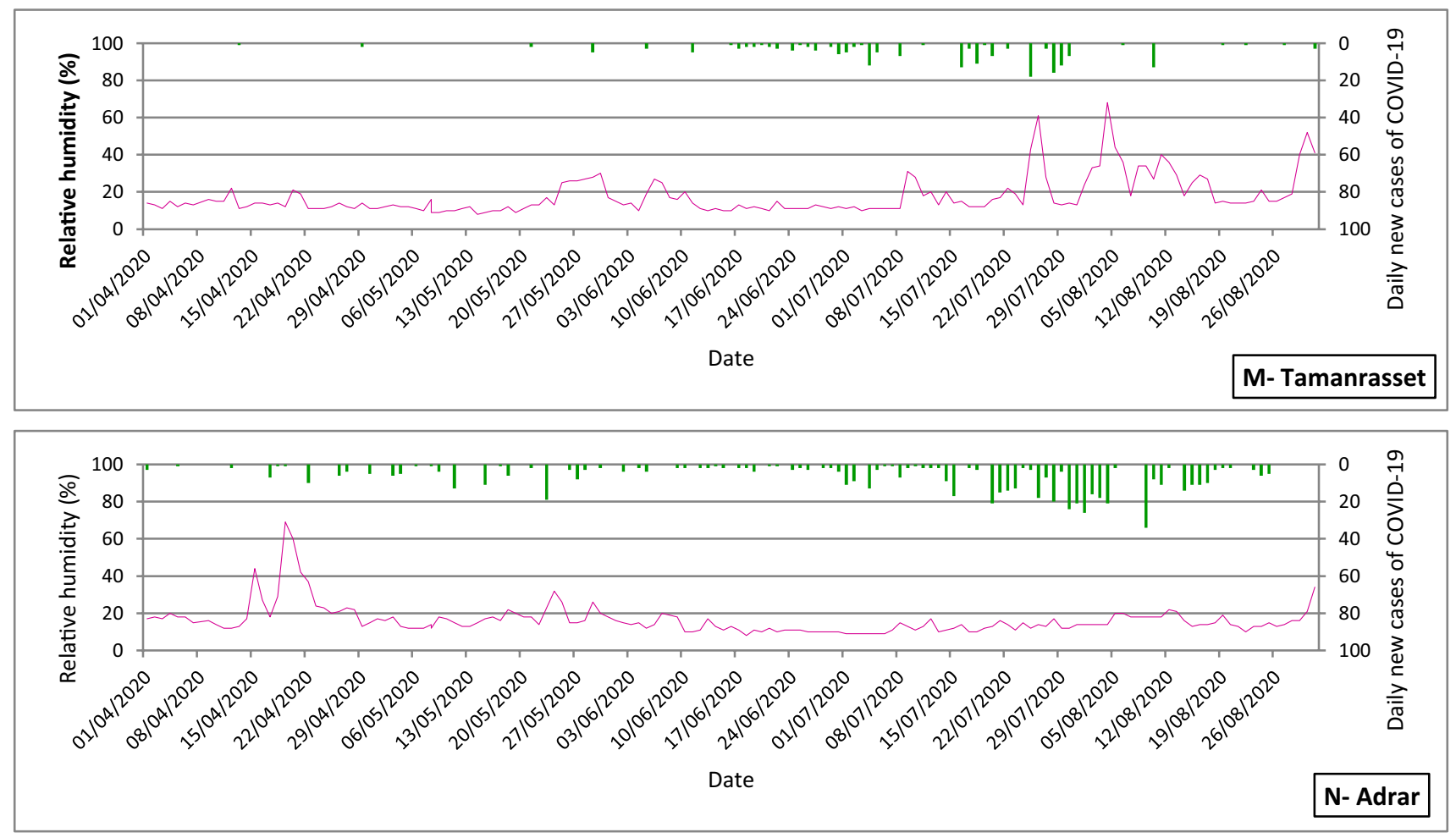

Fig. 9 Variation of RHD and daily new cases of COVID-19 in the hyper-arid regions (2 Algerian cities) (period: April 1, 2020, to August 31, 2020). Green, daily new cases of COVID-19; pink, RHD 

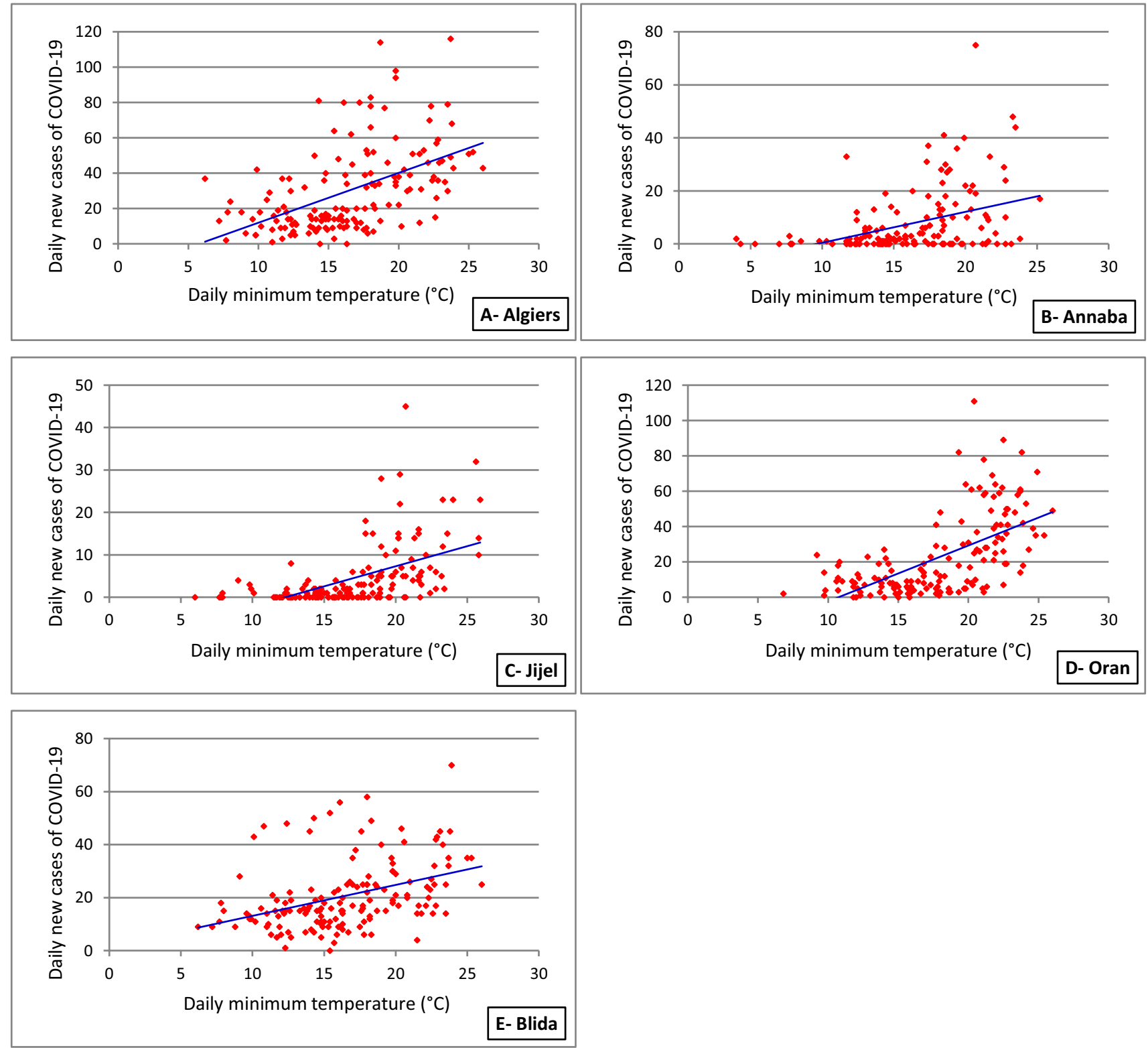

Fig. 10 Scatter diagrams for correlation between daily TMIN and new cases of COVID-19 in the sub-humid to humid regions (5 Algerian cities) (period: April 1, 2020, to August 31, 2020). Red diamond, daily new cases of COVID-19; blue line, line of the best fit

After the discovery of the vaccine by some laboratories and before vaccination of $70 \%$ of the world's population, living with the virus has become an inevitable reality. The containment measures must be followed to stop other epidemic wave that is plaguing the world. Furthermore, it is necessary to apply the sanitary procedures to slow down the COVID-19 transmission such as wearing masks. We can think that the mask, by reducing the viral load, would allow its wearer to develop less symptomatic forms of the disease and, at the same time, to acquire protection against COVID19. Moreover, several in-home measures such as liquid chlorine, alcohol, and sanitizer to prevent the spread of infection have been adopted from community (Das et al. 2021). Also, the physical distancing among with an establishment a field monitoring to observe the extent of compliance with the health protocol is mandatory. This immunization, on a global population scale, could then prove to be a valuable weapon against the pandemic. 

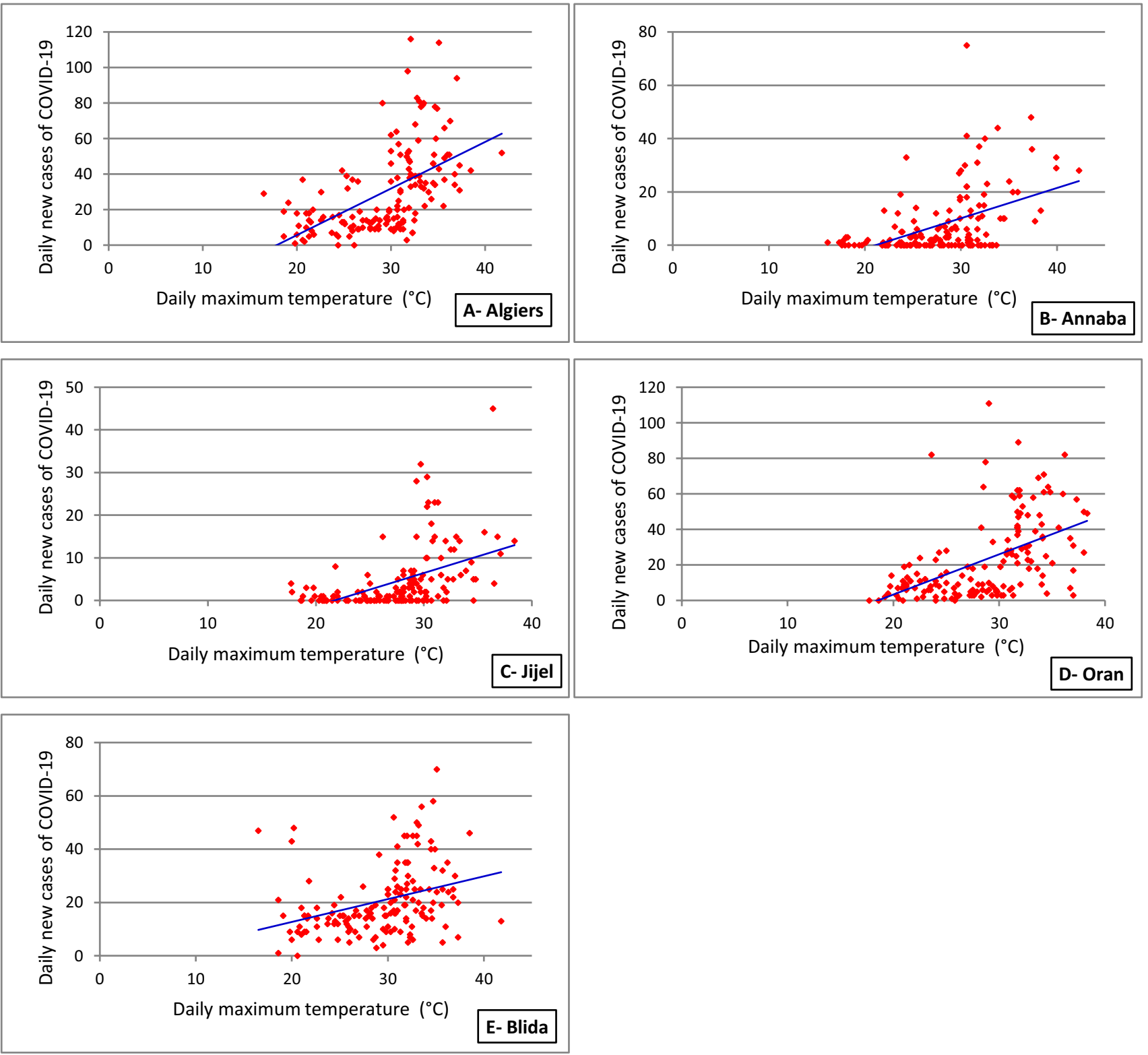

Fig. 11 Scatter diagrams for correlation between daily TMAX and new cases of COVID-19 in the sub-humid to humid regions (5 Algerian cities) (period: April 1, 2020, to August 31, 2020). Red diamond, daily new cases of COVID-19; blue line, line of the best fit 

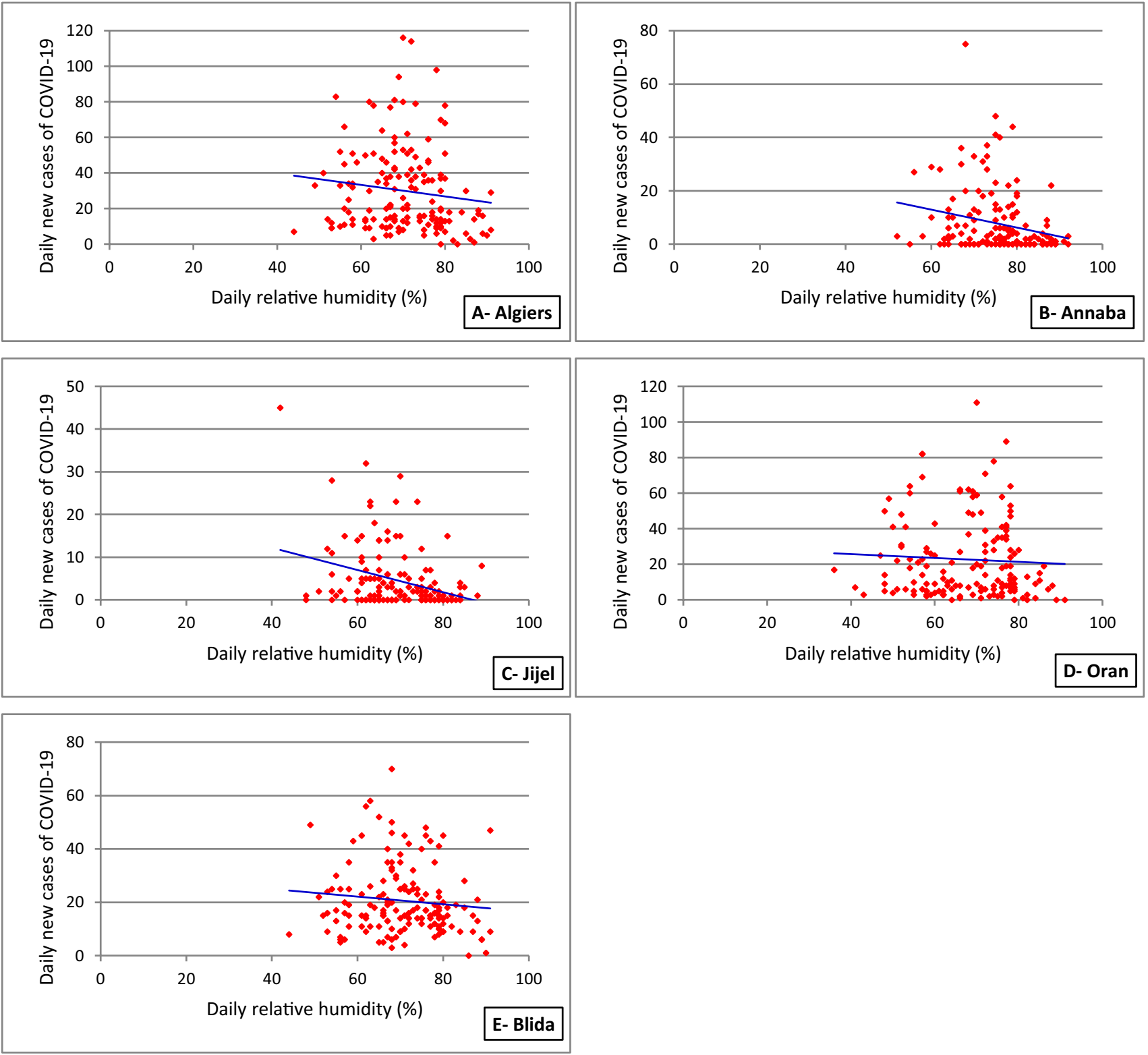

Fig. 12 Scatter diagrams for correlation between daily RHD and new cases of COVID-19 in the sub-humid to humid regions (5 Algerian cities) (period: April 1, 2020, to August 31, 2020). Red diamond, daily new cases of COVID-19; blue line, line of the best fit 

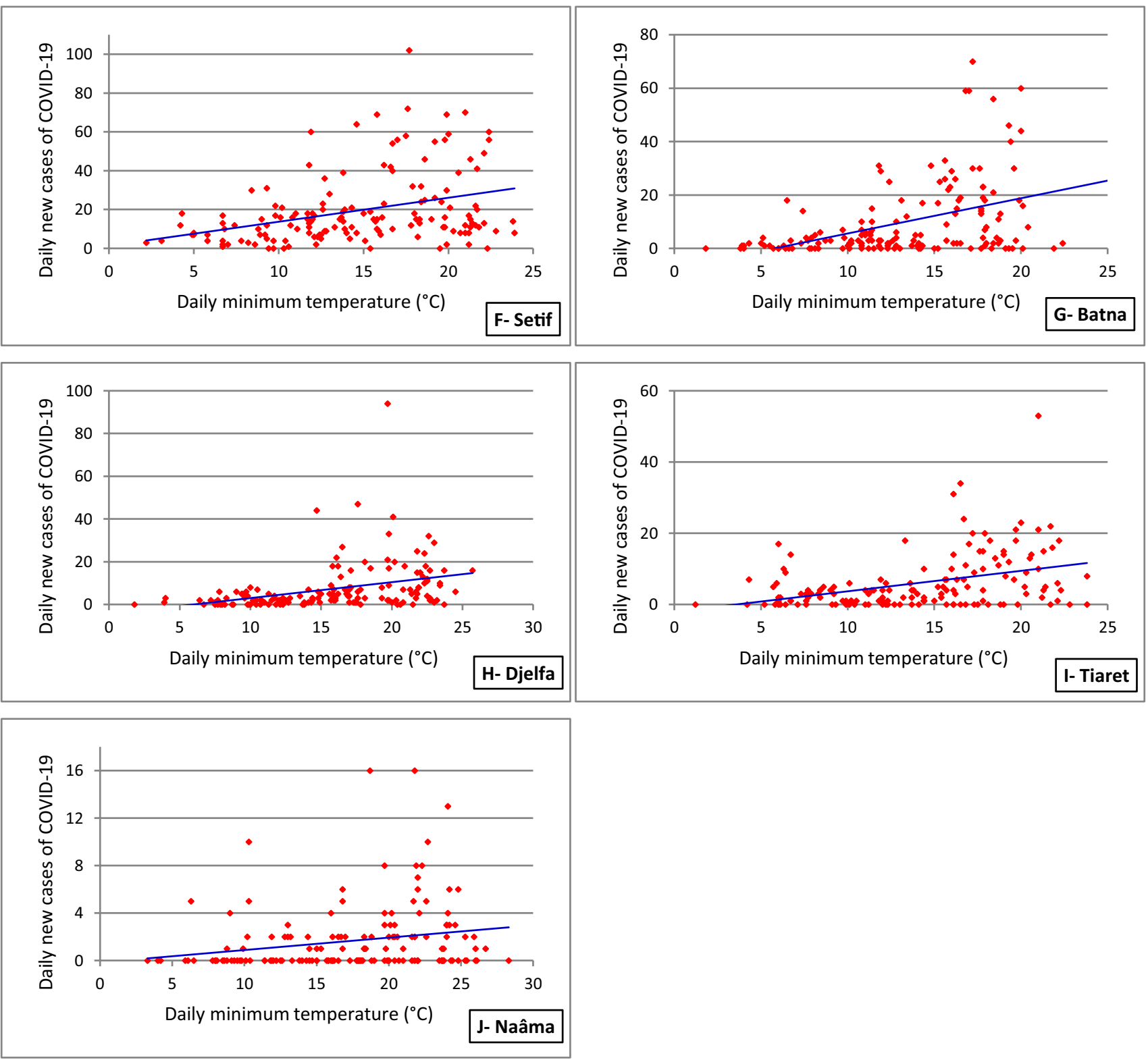

Fig. 13 Scatter diagrams for correlation between daily TMIN and new cases of COVID-19 in the semi-arid regions (5 Algerian cities) (period: April 1, 2020, to August 31, 2020). Red diamond, daily new cases of COVID-19; blue line, line of the best fit 

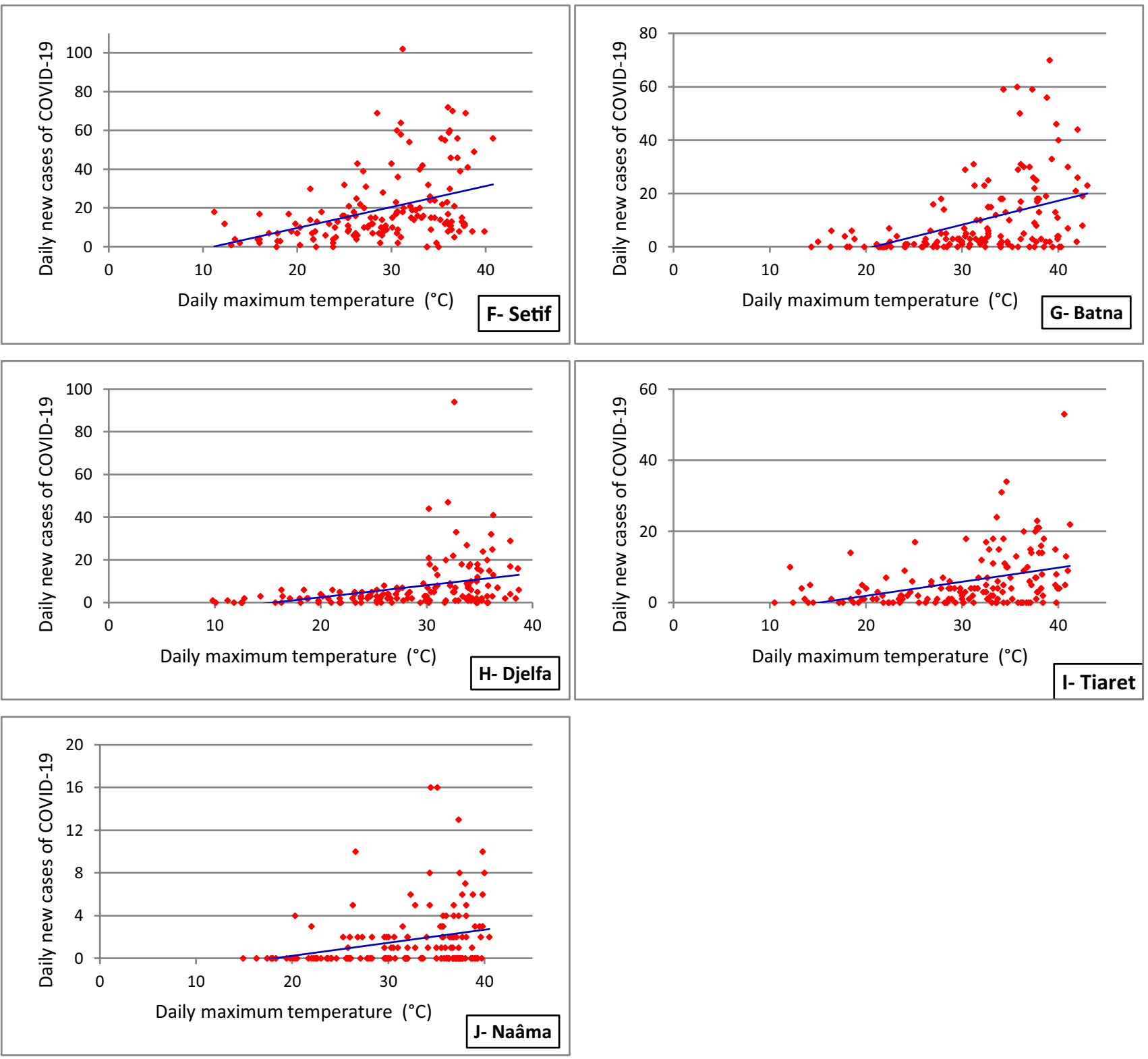

Fig. 14 Scatter diagrams for correlation between daily TMAX and new cases of COVID-19 in the semi-arid regions (5 Algerian cities) (period: April 1, 2020, to August 31, 2020). Red diamond, daily new cases of COVID-19; blue line, line of the best fit 

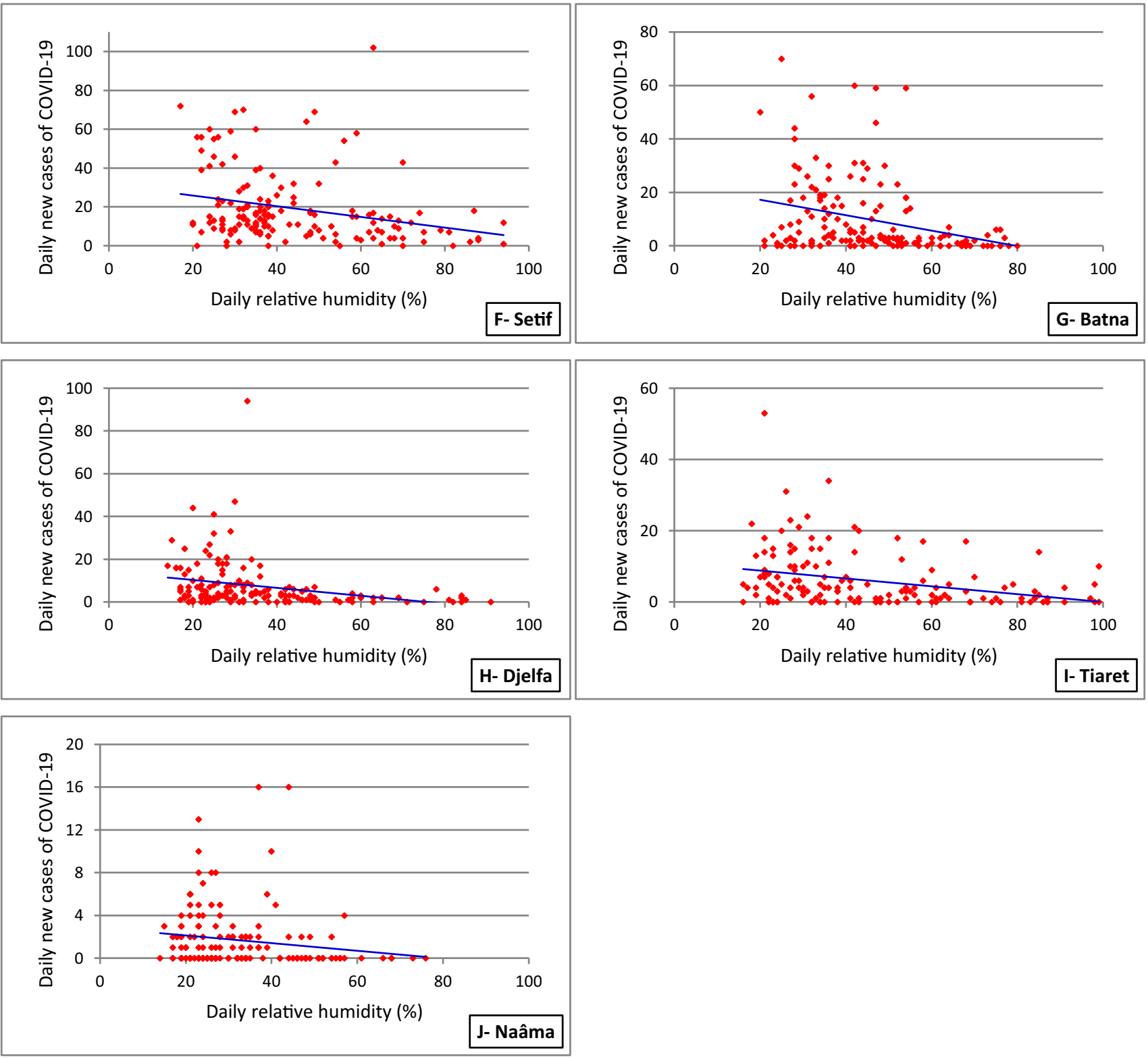

Fig. 15 Scatter diagrams for correlation between daily RHD and new cases of COVID-19 in the semi-arid regions (5 Algerian cities) (period: April 1, 2020, to August 31, 2020). Red diamond, daily new cases of COVID-19; blue line, line of the best fit 
Table 4 Results of the linear regression performed between daily TMIN, TMAX, RHD, and daily new cases of COVID-19

\begin{tabular}{|c|c|c|c|c|}
\hline Region climate & Cities & Model formula & $R^{2}$ & $R$ \\
\hline \multicolumn{5}{|c|}{ Correlation between daily TMIN and new cases of COVID-19 } \\
\hline \multirow[t]{5}{*}{ Sub-humid to humid } & Algiers & $y=2.820 x-16.300$ & 0.238 & 0.488 \\
\hline & Annaba & $y=1.164 x-11.300$ & 0.158 & 0.398 \\
\hline & Jijel & $y=0.949 x-11.680$ & 0.222 & 0.471 \\
\hline & Oran & $y=3.165 x-34.050$ & 0.248 & 0.498 \\
\hline & Blida & $y=1.165 x-1.501$ & 0.153 & 0.391 \\
\hline \multirow[t]{5}{*}{ Semi-arid } & Setif & $y=1.237 x-1.361$ & 0.121 & 0.348 \\
\hline & Batna & $y=1.322 x-7.645$ & 0.200 & 0.447 \\
\hline & Djelfa & $y=0.742 x-4.403$ & 0.119 & 0.345 \\
\hline & Tiaret & $y=0.573 x-2.026$ & 0.145 & 0.381 \\
\hline & Naâma & $y=0.105 x-0.171$ & 0.045 & 0.212 \\
\hline \multirow[t]{2}{*}{ Arid } & Ouargla & $y=0.694 x-8.745$ & 0.128 & 0.356 \\
\hline & Bechar & $y=0.023 x+1.718$ & 0.001 & 0.100 \\
\hline \multirow[t]{2}{*}{ Hyper-arid } & Tamanrasset & $y=0.154 x-2.150$ & 0.026 & 0.161 \\
\hline & Adrar & $y=0.218 x-1.502$ & 0.033 & 0.182 \\
\hline \multicolumn{5}{|c|}{ Correlation between daily TMAX and new cases of COVID-19 } \\
\hline \multirow[t]{5}{*}{ Sub-humid to humid } & Algiers & $y=2.619 x-46.730$ & 0.237 & 0.487 \\
\hline & Annaba & $y=1.136 x-23.970$ & 0.224 & 0.473 \\
\hline & Jijel & $y=0.779 x-16.940$ & 0.223 & 0.472 \\
\hline & Oran & $y=2.262 x-41.860$ & 0.240 & 0.490 \\
\hline & Blida & $y=0.857 x-4.478$ & 0.110 & 0.332 \\
\hline \multirow[t]{5}{*}{ Semi-arid } & Setif & $y=1.081 x-11.670$ & 0.155 & 0.394 \\
\hline & Batna & $y=0.899 x-18.690$ & 0.179 & 0.423 \\
\hline & Djelfa & $y=0.560 x-8.715$ & 0.120 & 0.346 \\
\hline & Tiaret & $y=0.394 x-5.979$ & 0.140 & 0.374 \\
\hline & Naâma & $y=0.121 x-2.194$ & 0.075 & 0.274 \\
\hline \multirow[t]{2}{*}{ Arid } & Ouargla & $y=0.609 x-15.940$ & 0.123 & 0.351 \\
\hline & Bechar & $y=0.045 x+0.655$ & 0.030 & 0.173 \\
\hline \multirow[t]{2}{*}{ Hyper-arid } & Tamanrasset & $y=0.247 x-7.572$ & 0.033 & 0.182 \\
\hline & Adrar & $y=0.254 x-6.511$ & 0.047 & 0.217 \\
\hline \multicolumn{5}{|c|}{ Correlation between daily RHD and new cases of COVID-19 } \\
\hline \multirow[t]{5}{*}{ Sub-humid to humid } & Algiers & $y=-0.323 x+52.750$ & 0.016 & 0.126 \\
\hline & Annaba & $y=-0.338 x+33.240$ & 0.053 & 0.230 \\
\hline & Jijel & $y=-0.260 x+22.640$ & 0.105 & 0.324 \\
\hline & Oran & $y=-0.109 x+30.160$ & 0.030 & 0.173 \\
\hline & Blida & $y=-0.141 x+30.580$ & 0.011 & 0.105 \\
\hline \multirow[t]{5}{*}{ Semi-arid } & Setif & $y=-0.274 x+31.340$ & 0.072 & 0.268 \\
\hline & Batna & $y=-0.289 x+23.060$ & 0.092 & 0.303 \\
\hline & Djelfa & $y=-0.185 x+14.020$ & 0.084 & 0.290 \\
\hline & Tiaret & $y=-0.100 x+11.050$ & 0.100 & 0.316 \\
\hline & Naâma & $y=-0.036 x+2.861$ & 0.028 & 0.167 \\
\hline \multirow[t]{2}{*}{ Arid } & Ouargla & $y=-0.311 x+14.950$ & 0.074 & 0.272 \\
\hline & Bechar & $y=-0.018 x+2.612$ & 0.001 & 0.032 \\
\hline \multirow[t]{2}{*}{ Hyper-arid } & Tamanrasset & $y=-0.004 x+1.213$ & 0.001 & 0.100 \\
\hline & Adrar & $y=-0.089 x+5.538$ & 0.012 & 0.110 \\
\hline
\end{tabular}



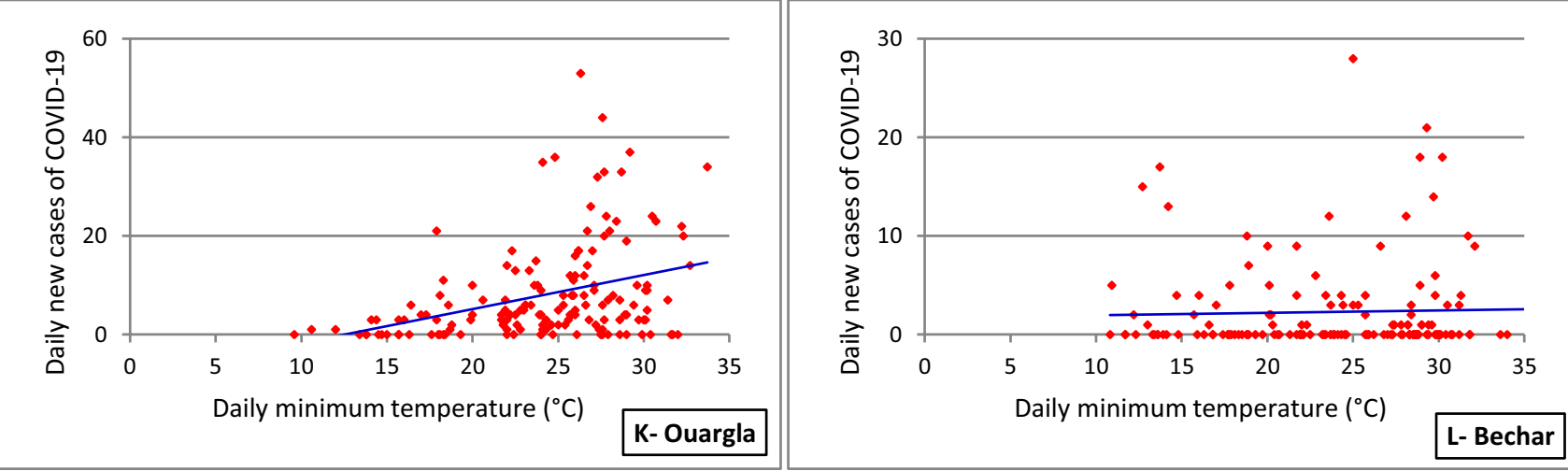

Fig. 16 Scatter diagrams for correlation between daily TMIN and new cases of COVID-19 in the arid regions (2 Algerian cities) (period: April 1, 2020, to August 31,2020). Red diamond, daily new cases of COVID-19; blue line, line of the best fit
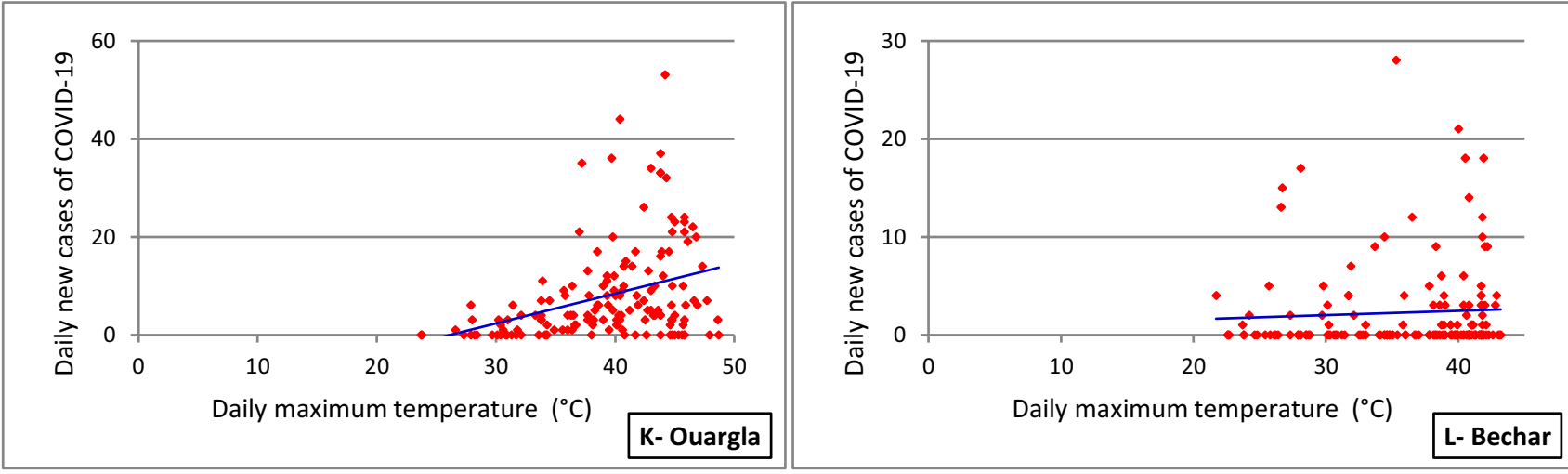

Fig. 17 Scatter diagrams for correlation between daily TMAX and new cases of COVID-19 in the arid regions (2 Algerian cities) (period: April 1, 2020, to August 31, 2020). Red diamond, daily new cases of COVID-19; blue line, line of the best fit
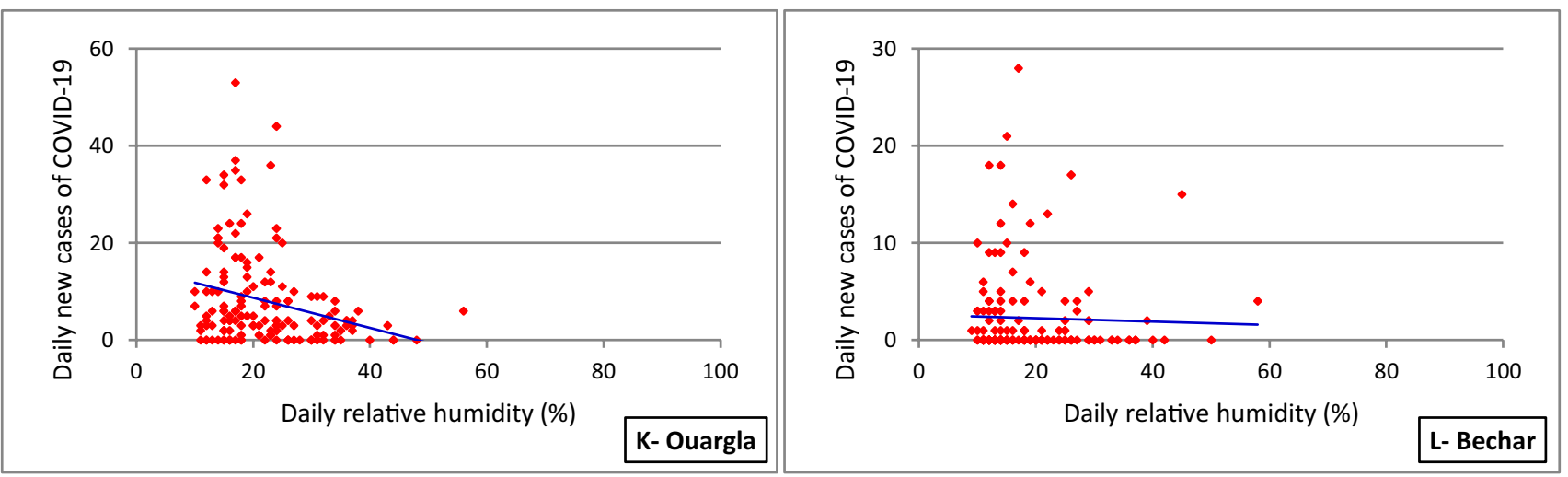

Fig. 18 Scatter diagrams for correlation between daily RHD and new cases of COVID-19 in the arid regions (2 Algerian cities) (period: April 1, 2020, to August 31, 2020). Red diamond, daily new cases of COVID-19; blue line, line of the best fit 

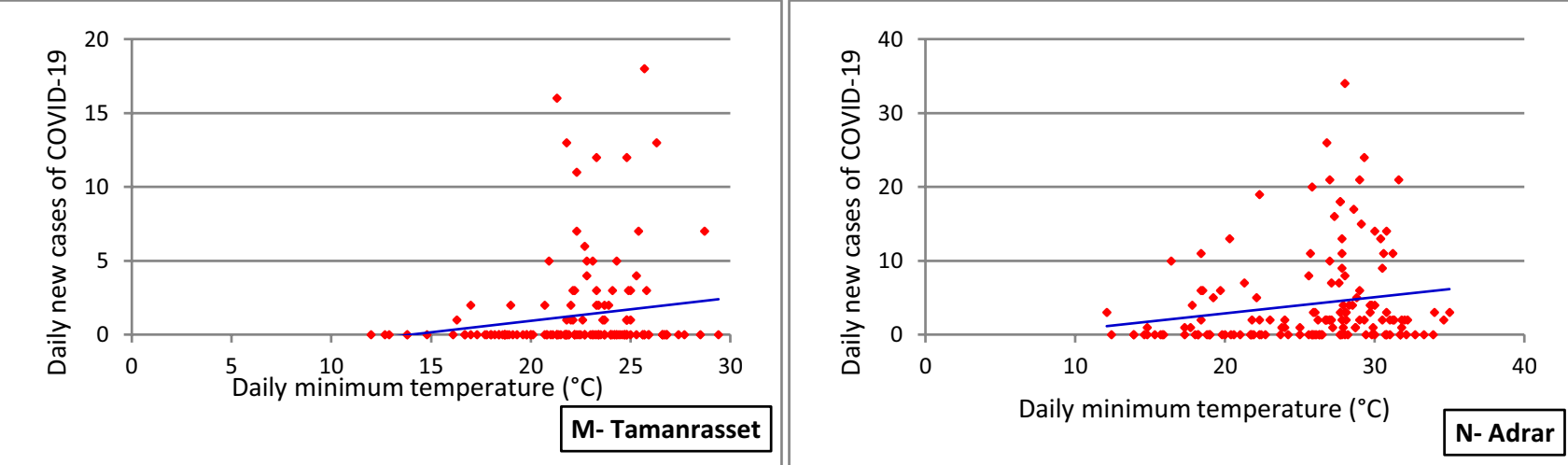

Fig. 19 Scatter diagrams for correlation between daily TMIN and new cases of COVID-19 in the hyper-arid regions (2 Algerian cities) (period: April 1, 2020, to August 31, 2020). Red diamond, daily new cases of COVID-19; blue line, line of the best fit
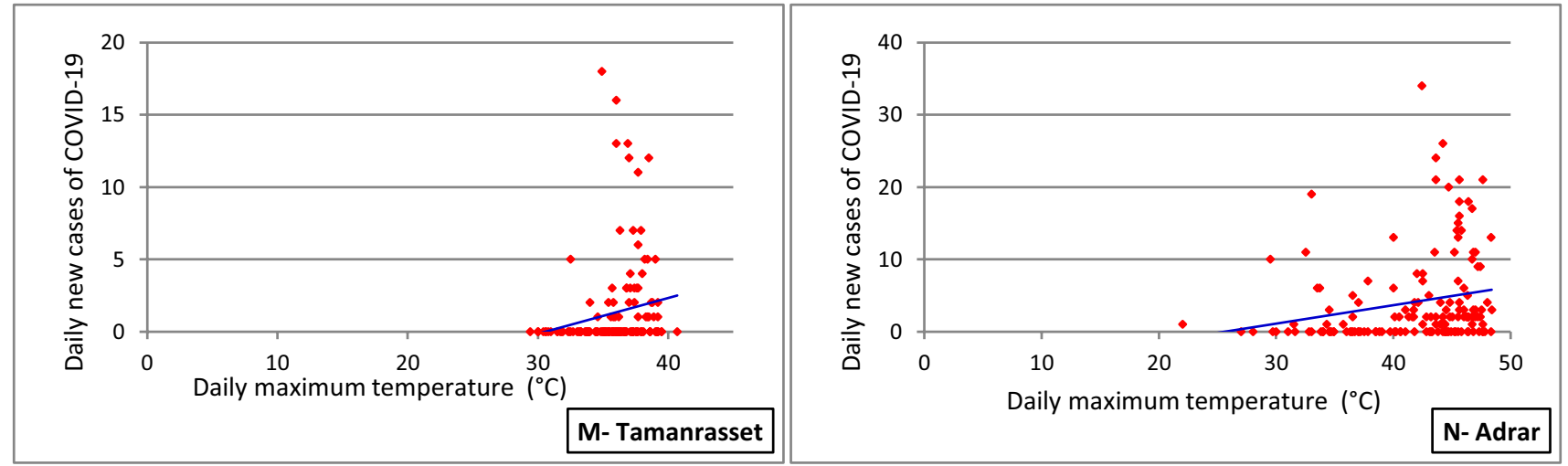

Fig. 20 Scatter diagrams for correlation between daily TMAX and new cases of COVID-19 in the hyper-arid regions (2 Algerian cities) (period: April 1, 2020, to August 31, 2020). Red diamond, daily new cases of COVID-19; blue line, line of the best fit
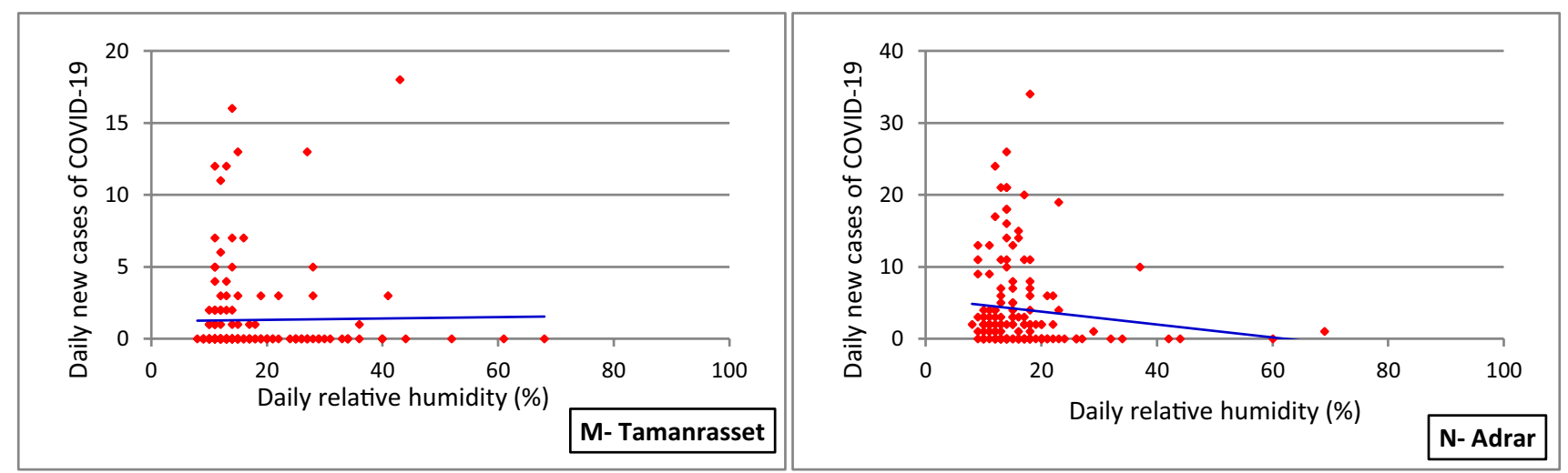

Fig. 21 Scatter diagrams for correlation between daily RHD and new cases of COVID-19 in the hyper-arid regions (2 Algerian cities) (period: April 1, 2020, to August 31, 2020). Red diamond, daily new cases of COVID-19; blue line, line of the best fit 
Author contribution Abdelmadjid Boufekane conducted the literature review, prepared the datasets, interpreted the results, and drafted and finalized the manuscript; Gianluigi Busico contributed to the conception of the meta-analysis, interpreted the findings, and assisted in finalizing the manuscript; Djamel Maizi contributed to the literature review and dataset preparation. All authors have read and approved the manuscript.

Data availability The datasets used and analyzed during the current study are available from the corresponding author on reasonable request.

\section{Declarations}

Ethics approval Not applicable.

Consent to participate Not applicable.

Consent for publication Not applicable.

Competing interests The authors declare no competing interests.

\section{References}

Auler AC, Cássaro FAM, da Silva VO, Pires LF (2020) Evidence that high temperatures and intermediate relative humidity might favor the spread of COVID-19 in tropical climate: a case study for the most affected brazilian cities. Sci Total Environ 729:139090. https://doi.org/10.1016/j.scitotenv.2020.139090

Das AK, Islam MN, Billah MM, Sarker A (2021) COVID19 and municipal solid waste (MSW) management: a review. Environ Sci Pollut Res. https://doi.org/10.1007/ s11356-021-13914-6

Davis RE, Dougherty E, McArthur C, Huang QS, Baker MG (2016a) Cold, dry air is associated with influenza and pneumonia mortality in Auckland, New Zealand. Influenza Other Respir Viruses 10(4):310-313. https://doi.org/10.1111/irv.12369

Davis RE, McGregor GR, Enfield KB (2016b) Humidity: a review and primer on atmospheric moisture and human health. Environ Res 144:106-116. https://doi.org/10.1016/j.envres.2015.10.014

Doğan B, Ben Jebli M, Shahzad K, Hassan Farooq T, Shahzad U (2020) Investigating the effects of meteorological parameters on COVID-19: case study of New Jersey, United States. Environ Res 191:110148. https://doi.org/10.1016/j.envres.2020.110148

Gorbalenya AE (2020) Severe acute respiratory syndrome-related coronavirus-the species and its viruses, a statement of the Coronavirus Study Group. BioRxiv 1-15. https://doi.org/10.1101/2020.02.07.937862

Jaccard J, Guilamo-Ramos V, Johansson M, Bouris A (2006) Multiple regression analyses in clinical child and adolescent psychology. J Clin Child Adolesc Psychol 35(3):456-479. https://doi.org/10. 1207/s15374424jecp3503_11

Kudo E, Song E, Yockey LJ, Rakib T, Wong PW, Homer RJ, Iwasaki A (2019) Low ambient humidity impairs barrier function and innate resistance against influenza infection. Proc Natl Acad Sci U S A 116(22):10905-10910. https://doi.org/10.1073/pnas.1902840116

Liu J, Zhou J, Yao J, Zhang X, Li L, Xu X, He X, Wang B, Fu S, Niu T, Yan J, Shi Y, Ren X, Niu J, Zhu W, Li S, Luo B, Zhang K (2020) Impact of meteorological factors on the COVID-19 transmission: a multi-city study in China. Sci Total Environ 726:138513. https:// doi.org/10.1016/j.scitotenv.2020.138513

Marr LC, Tang JW, Van Mullekom J, Lakdawala SS (2019) Mechanistic insights into the effect of humidity on airborne influenza virus survival, transmission and incidence. J R Soc Interface 16(150):20180298. https://royalsocietypublishing.org/doi/https:// doi.org/10.1098/rsif.2018.0298

Metz JA, Finn A (2015) Influenza and humidity - why a bit more damp may be good for you! J Infect 71:S54-S58. https://doi.org/ 10.1016/j.jinf.2015.04.013

Moriyama M, Ichinohe T (2019) High ambient temperature dampens adaptive immune, responses to influenza A virus infection. Proc Natl Acad Sci U S A 116(8):3118-3125. https://doi.org/10.1073/ pnas. 1815029116

Moriyama M, Hugentobler WJ, Iwasaki A (2020) Seasonality of respiratory viral infections. Ann Rev Virol 7:83-101. https://doi.org/ 10.1146/annurev-virology-012420-022445

Núñez-Delgado A (2020) What do we know about the SARS-CoV-2 coronavirus in the environment? Sci Total Environ 727:138647. https://doi.org/10.1016/j.scitotenv.2020.138647

Oliveiros B, Caramelo L, Ferreira NC, Caramelo F (2020) Role of temperature and humidity in the modulation of the doubling time of COVID-19 cases. medRxiv 1-13. https://doi.org/10.1101/2020. 03.05.20031872

Peci A, Winter AL, Li Y, Gnaneshan S, Liu J, Mubareka S, Gubbay JB (2019) Effects of absolute humidity, relative humidity, temperature, and wind speed on influenza activity in Toronto, Ontario, Canada. Appl Environ Microbiol 85(6):e02426-18. https://aem. asm.org/content/85/6/e02426-18

Prata DN, Rodrigues W, Bermejo PH (2020) Temperature significantly changes COVID-19 transmission in (sub) tropical cities of Brazil. Sci Total Environ 729:138862. https://doi.org/10.1016/j.scitotenv. 2020.138862

Qi H, Xiao S, Shi R, Ward MP, Chen Y, Tu W, Su Q, Wang W, Wang $X$, Zhang Z (2020) COVID-19 transmission in Mainland China is associated with temperature and humidity: a time-series analysis. Sci Total Environ 728:138778. https://doi.org/10.1016/j.scitotenv. 2020.138778

Rendana M (2020) Impact of the wind conditions on COVID-19 pandemic: a new insight for direction of the spread of the virus. Urban Climate 34:100680. https://www.sciencedirect.com/science/artic le/abs/pii/S2212095520302509

Shahzad K, Hassan Farooq T, Doğan B, Hu LZ, Shahzad U (2021) Does environmental quality and weather induce COVID-19: case study of Istanbul, Turkey. Environ Forensics. https://doi.org/10. 1080/15275922.2021.1940380

Steel J, Palese P, Lowen AC (2011) Transmission of a 2009 pandemic influenza virus shows a sensitivity to temperature and humidity similar to that of an H3N2 seasonal strain. J Virol 85(3):14001402. https://doi.org/10.1128/JVI.02186-10

Sun Z, Thilakavathy K, Kumar SS, He G, Liu SV (2020) Potential factors influencing repeated SARS outbreaks in China. Int J Environ Res Public Health 17(5):1633. https://doi.org/10.3390/ijerph1705 1633

Tian F, Liu X, Chao Q, Qian ZM, Zhang S, Qi L, Niu Y, Arnold LD, Zhang S, Li H, Lin H, Liu Q (2021) Ambient air pollution and low temperature associated with case fatality of COVID-19: a nationwide retrospective cohort study in China. Innovation 2:100139. https://doi.org/10.1016/j.xinn.2021.100139

Tosepu R, Gunawan J, Effendy DS, Ahmad LOAI, Lestari H, Bahar H, Asfian P (2020) Correlation between weather and COVID-19 pandemic in Jakarta, Indonesia. Sci Total Environ 728:138810. https://doi.org/10.1016/j.scitotenv.2020.138436

United Nations Development Program (2020) COVID-19 pandemic Humanity needs leadership andsolidarity to defeat the coronavirus. https://www.undp.org/content/undp/en/home/coronavirus.html

Wang C, Horby PW, Hayden FG, Gao GF (2020a) A novel coronavirus outbreak of global health concern. Lancet 395(10223):470-473. https://doi.org/10.1016/S0140-6736(20)30185-9 
Wang M, Jiang A, Gong L, Luo L, Guo W, Li C, Zheng J, Li C, Yang B, Zeng J (2020b) Temperature significant change COVID-19 transmission in 429 cities. medRxiv 1-19. https://doi.org/10.1101/ 2020.02.22.20025791

World Health Organization (2020) Novel coronavirus (2019-nCoV) situation report 7 - January 27, 2020. https://www.who.int/docs/ default-source/coronaviruse/situation-reports/20200127-sitrep-72019--ncov.pdf?sfvrsn=98ef79f5_2

Wu F, Zhao S, Yu B, Chen Y, Wang W, Song Z, Hu Y, Tao Z, Tian J, Pei Y, Yuan M, Zhang Y, Dai F, Liu Y, Wang Q, Zheng J, Xu L, Holmes EC, Zhang Y (2020) A new coronavirus associated with human respiratory disease in China. Nature 579(7798):265-269. https://doi.org/10.1038/s41586-020-2008-3

Xu Z, Shi L, Wang Y, Zhang J, Huang L, Zhang C, Liu S, Zhao P, Liu H, Zhu L (2020) Pathological findings of COVID-19 associated with acute respiratory distress syndrome. Lancet Respir Med 8(4):P420-422. https://doi.org/10.1016/S2213-2600(20)30076-X
Yao Y, Pan J, Liu Z, Meng X, Wang W, Kan H, Wang W (2020) No association of COVID-19 transmission with temperature or UV radiation in Chinese cities. Eur Respir J 55:2000517. https://doi. org/10.1183/13993003.00517-2020

Yongjiana Z, Jingubc X, Fengmingb H, Liqingb C (2020) Association between short term exposure to air pollution and COVID-19 infection: evidence from China. Sci Total Environ 727:138704. https:// doi.org/10.1016/j.scitotenv.2020.138704

Zhu Y, Xie J (2020) Association between ambient temperature and COVID-19 infection in122 cities from China. Sci Total Environ 724:138201. https://doi.org/10.1016/j.scitotenv.2020.138201

Publisher's note Springer Nature remains neutral with regard to jurisdictional claims in published maps and institutional affiliations. 